\title{
A Framework for Better Evaluations of Supply Chain Collaborations: Evidence from the Dutch Fast Moving Consumer Goods Industry
}

Citation for published version (APA):

Jung, V., Peeters - Rutten, M., \& Vredeveld, T. (2017). A Framework for Better Evaluations of Supply Chain Collaborations: Evidence from the Dutch Fast Moving Consumer Goods Industry. Maastricht University, Graduate School of Business and Economics. GSBE Research Memoranda No. 014 https://doi.org/10.26481/umagsb.2017014

Document status and date:

Published: 22/05/2017

DOI:

10.26481/umagsb.2017014

Document Version:

Publisher's PDF, also known as Version of record

Please check the document version of this publication:

- A submitted manuscript is the version of the article upon submission and before peer-review. There can be important differences between the submitted version and the official published version of record.

People interested in the research are advised to contact the author for the final version of the publication, or visit the DOI to the publisher's website.

- The final author version and the galley proof are versions of the publication after peer review.

- The final published version features the final layout of the paper including the volume, issue and page numbers.

Link to publication

\footnotetext{
General rights rights.

- You may freely distribute the URL identifying the publication in the public portal. please follow below link for the End User Agreement:

www.umlib.nl/taverne-license

Take down policy

If you believe that this document breaches copyright please contact us at:

repository@maastrichtuniversity.nl

providing details and we will investigate your claim.
}

Copyright and moral rights for the publications made accessible in the public portal are retained by the authors and/or other copyright owners and it is a condition of accessing publications that users recognise and abide by the legal requirements associated with these

- Users may download and print one copy of any publication from the public portal for the purpose of private study or research.

- You may not further distribute the material or use it for any profit-making activity or commercial gain

If the publication is distributed under the terms of Article $25 \mathrm{fa}$ of the Dutch Copyright Act, indicated by the "Taverne" license above, 
Verena Jung, Marianne Peeters, Tjark Vredeveld

A Framework for Better Evaluations of Supply Chain Collaborations: Evidence from the Dutch Fast Moving Consumer Goods Industry

$\mathrm{RM} / 17 / 014$

\section{GSBE}

Maastricht University School of Business and Economics

Graduate School of Business and Economics

\section{P.O Box 616}

NL- 6200 MD Maastricht

The Netherlands 


\title{
A Framework for Better Evaluations of Supply Chain Collaborations: Evidence from the Dutch Fast Moving Consumer Goods Industry
}

\author{
Verena Jung, Marianne Peeters and Tjark Vredeveld
}

Purpose - The purpose of this paper is to develop a framework to better evaluate potential supply chain collaborations (SCCS).

Design/methodology/approach - Prior research is used to develop a conceptual framework of all relevant factors, both drivers and resistors, which is, next, empirically tested in the Dutch fast moving consumer goods (FMCG) industry.

Findings - The study provides a complete overview of all potential factors that should be evaluated before starting SSCs, categorized in "benefits", "forces", "enablers/barriers" and "risks".

Research limitations/implications - The sample of the study only consists of parties from one Dutch industry. Further research in other geographical areas and/or industries may result in stronger support. Furthermore, the importance of each driver and resistor has not been quantified for the specific party and collaboration. Quantifying the factors for each party might be beneficial and should also be considered in further research.

Practical implications - The study provides a checklist containing all potential factors for all parties involved.

Originality/value -This paper enriches the supply chain management (SCM) literature with an extensive specification of all potential drivers and resistors for starting SCCS structured in a framework.

\section{Introduction}

In the last decades companies realized the need for looking outside their organizational boundaries for new opportunities. This is due to various factors such as a constantly growing competition amongst organizations and higher customer expectations (Cao and Zhang, 2011; Lambert et al., 1996; Simatupang and Sridharan, 2002). According to Horvath (2001), a new vital base of competitive advantage that has not yet been fully exploited and, thus, offers a huge potential for growth and performance improvements is supply chain collaboration (SCC). Nowadays, SCC is a widely discussed topic and it means that "two or more independent companies work jointly to plan and execute [...] operations with greater success than when acting in isolation" (Simatupang and Sridharan, 2002).

Although the idea of SCC may sound easy in theory, collaborations in practice often fail (Sabath and Fontanella, 2002). According to Daugherty et al. (2006), SCC promises theoretically huge benefits but it appears that reality falls short, which indicates a gap between theory and practice. Multiple drivers and resistors have to be taken into account by all parties involved before a SCC can be started. 
However, these drivers and resistors are often unknown or misunderstood by the parties, which might lead to the fact that SCCs likely fail. To avoid this, a complete overview of all potential drivers and resistors has to be provided to the parties. From this complete overview the parties can identify their relevant drivers and resistors for the specific SCC (Autry, 2011).

Although prior research has widely discussed potential drivers and resistors, until now there is no study that includes all drivers and resistors. For example, Ahmad and Ullah (2013) discuss potential benefits of SCCs and factors, which enable a party to start SCCs. Next to that, Cruijssen et al. (2007) discuss potential threats and impediments to start SCCs, whereas, de Leeuw and Fransoo (2009) only mention external factors which force a party to start SCCs. Furthermore, there exists some ambiguity and incompleteness in literature. Given that many SCCs fail in practice due to misunderstandings of or not evaluating all relevant drivers and resistors, it is necessary that a complete overview of all potential drivers and resistors, using consistent terminology and definitions, is provided.

The purpose of the research is to create a framework that provides this complete overview of all potential drivers and resistors for starting SCCs. This paper is an extended version of the paper by Jung et al. (2017), in which the authors only show an example for the framework. In addition to that, this paper presents the final framework of factors divided into four categories. The diverse terms for factors used in prior research and in practice, are clustered into clearly defined general factors. Moreover, Jung et al. (2017) only mention preliminary results, in this paper the complete analysis is presented. The remainder of the paper is organized as follows. In Section 2 a critical discussion of an extensive literature review is given and based on this the conceptual framework is created. Next, the completeness of this framework in practice is investigated. The research methodology is explained in Section 3. This is followed by the analysis of the interviews. The paper concludes with a discussion of the results as well as limitations and future research. Moreover, the contribution to the supply chain management (SCM) literature is explained and valuable practical implications are provided.

\section{Theoretical development}

Until now a great number of researchers tried to identify relevant drivers and resistors for SCC, but there exists some ambiguity and incompleteness in literature. Through an extensive literature review, two different kinds of ambiguity for the drivers can be identified. The first kind of ambiguity is that the same terms are used for different categories of drivers and that no unique term for the identified categories exists. Examples are the terms "drivers" and "driving forces". Ahmad and Ullah (2013) use the term "drivers" to define two different categories. First, they use the term to define factors which enable someone to collaborate like "trust" or "commitment". Second, they use the term for expected benefits of a successful SCC like "improved customer service" or "increase in market share". Next to the term "drivers", they also use the term "driving forces" for the expected benefits. However, the term "driving forces" is used by Fawcett et al. (2008b) to define factors which force a party to collaborate like "more demanding customers" or "economic globalization". The second kind of ambiguity is that factors are assigned to more than one category. An example is the factor "trust", which is identified by Ahmad and Ullah (2013) as a factor which enables someone to collaborate and by Beach et al. (2005) as an outcome of SCCs. For the resistors a unique term and definition is also missing. However, in contrast to the drivers, most of the time only one category is named for resistors. But even for this single category multiple terms exists like "barriers" (e.g. Akintoye et al., 2000) or "impediments" (e.g. Cruijssen et al., 2007). Moreover, some kind of incompleteness can be observed, namely that an in earlier research identified factor is not present in more recent literature. An example is the factor "transparency" which is identified as a factor which enables someone to collaborate by Visser (2010), but it is not mentioned by Ahmad and Ullah (2013). 
Due to the ambiguity and incompleteness, the understanding and identification of all relevant drivers and resistors for the specific SCC represents a challenge for the parties. Therefore, a complete overview of all potential drivers and resistors is needed to better evaluate potential SCCs.

Drawing on prior research a conceptual framework is developed consisting of two umbrella terms. The first umbrella term is called "drivers" and the second one "resistors". The term "drivers" represents the various categories of the drivers identified in literature and for all the retarding factors, the umbrella term "resistors" is used. Next, the drivers are split into three different categories. The first category, benefits, represents the expected benefits of a successful SCC like "cost reduction" (e.g. Akintoye et al., 2000). The second category, forces, contains external factors which force a party to collaborate like "economic globalization" (e.g. Fawcett et al., 2008b). The last category, enablers, includes the factors which enable someone to collaborate, and, in addition, have an effect on the success of SCC like "trust" (Ahmad and Ullah, 2013). The distinction between the three driver categories is made to highlight the differences between the drivers. Benefits and forces are both motivating factors to collaborate. Nevertheless, there is a big difference. Benefits represent the intrinsic motivation which means that the party decides to collaborate out of its own motivation (Lambert et al., 1996). Therefore, the benefits usually have a positive influence on SCC. In contrast to that, the forces represent the extrinsic motivation. Here a party is forced to collaborate and, therefore, a change in management practices towards more SCC is dictated but not necessarily wished by the party itself. This can have a negative influence on collaborations (Fawcett et al., 2008b). Hence, it is important to understand that next to the resistors also the category forces can have a negative influence on SCCS. A strong motivation to build a SCC is not enough. Therefore, in addition to the two kinds of motivators, enablers are required. The enablers increase the probability of success and, therefore, have a positive influence on SCC (Lambert et al., 1996). Finally, the resistors are divided into two categories, which both have a negative influence on collaboration. The first category, barriers, consists of impediments that can obstruct the SCC and are known before the collaboration starts. An example is "lack of (top) management commitment" (e.g. Akintoye et al., 2000). The other category is called risks. Risks are future-oriented and include events that might occur in the future but are unknown yet, like "uncertainty of decreased competitiveness" (e.g. Maloni and Benton, 1997). This distinction is also mentioned by Evans (2012) in the context of strategic planning. Given that barriers are already known at the moment in time parties decide whether to collaborate or not, each party can already take actions against the barriers. In contrast to that, the risks are uncertain at this point in time. Because of this, the decision to collaborate or not is dependent on the decision makers and their risk preferences (risk averse, risk neutral or risk loving). Finally, a connection between the driver "enablers" and the resistor "barriers" is observed. For every enabler a corresponding barrier can be identified (Walker et al., 2008). An example is the enabler "trust" and the barrier "lack of trust" (e.g. Visser, 2010). To show this connection, the factors of these two categories are combined. When evaluating SCCs, the factor will be identified either as an enabler, "presence of...", or as a barrier, "lack of ...".

Based on the review of 34 studies from 1991 to 2013, 113 benefits, 32 forces, 83 barriers, 180 enablers and 56 risks were identified. To create a clear overview of all potential drivers and resistors, these factors have to be assigned to so-called general factors. Reported benefits as "environmental performance improvements", "minimizing waste and pollution" and "regeneration of local areas" (Walker et al., 2008) all refer to improvements in sustainability and are assigned to "sustainability improvements". In total 72 general factors were created; 10 general factors for the benefits, 9 for the forces, 36 for the enablers/barriers category and 17 for the risks. Figure 1 shows the resulting conceptual framework including definitions and explanations of the influences of the categories on SCC as well as some general factors for each category. The complete framework is shown in 
Appendix A and B, all factors identified from the 34 studies and the corresponding general factors are presented.

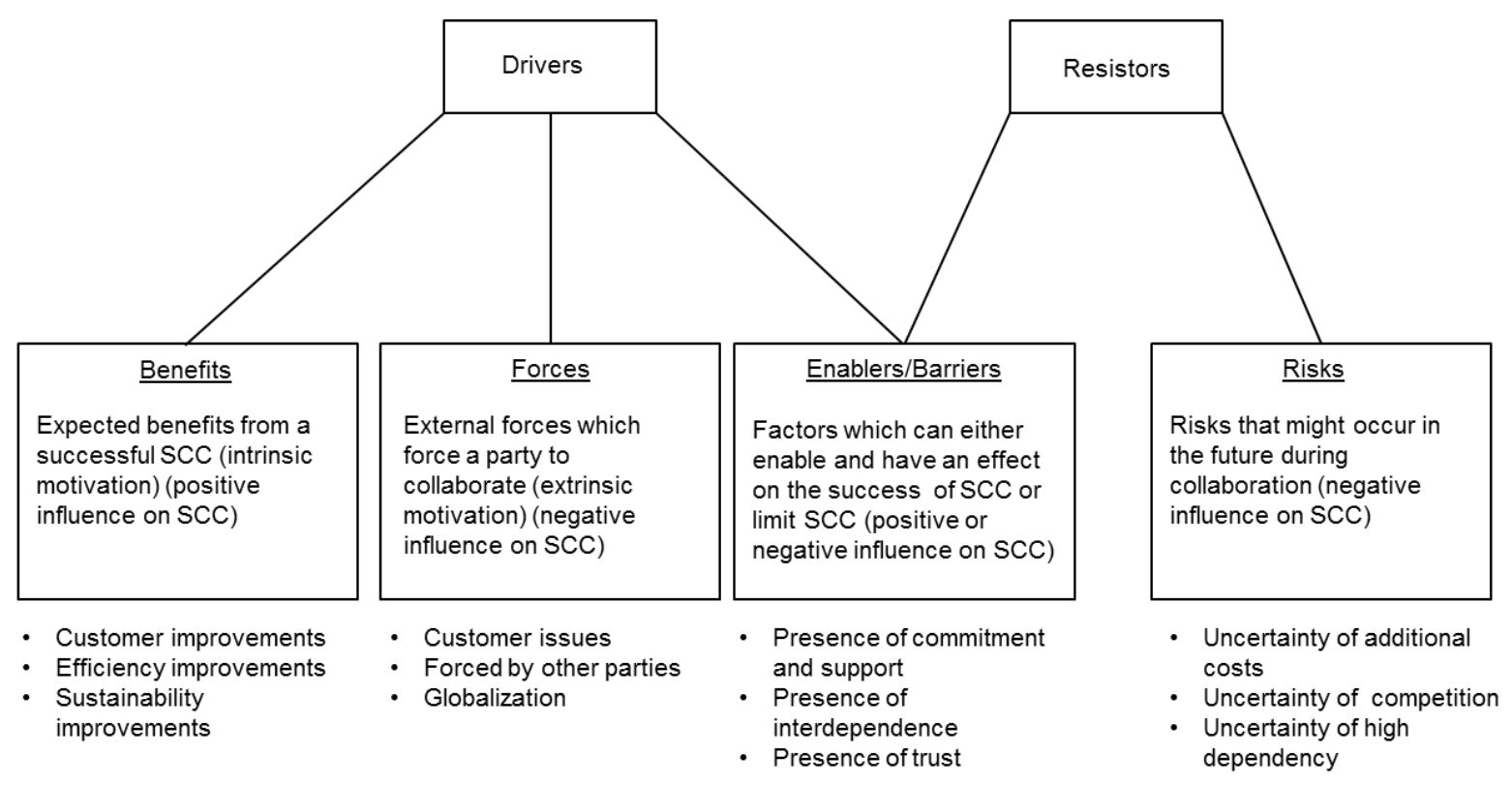

Figure1: The framework

Drawing on the above, it can only be concluded that the conceptual framework is complete in theory. The next step is to investigate whether the conceptual framework is also complete in practice.

\section{Research Methodology}

To test the completeness of the framework in practice, a case research approach is used. A qualitative research using individual semi-structured in-depth interviews is a common way to explore practice and collect data (Qu and Dumay, 2011; Yin, 2009). The population consisted of companies from the Dutch fast moving consumer goods (FMCG) industry. This industry has been selected because of the importance of SCC for this industry and the complexity of the SCCs. Referring to de Kok et al. (2015) "[t]he FMCG sector is core to the wealth and well-being of the developed countries". Nearly $20 \%$ of the total ton kilometres transported in the EU are goods from the FMCG industry (de Kok et al., 2015). In contrast to prior research, not only dyadic relationships, but also collaborations involving three - e.g. manufacturer, LSP and retailer - or even more independent parties were included. With this it can be investigated whether in more complex relationships, which are common in practice, additional factors are relevant for the involved parties. To enhance the reliability of the research a study protocol has been developed to create transparency regarding the approach used, thereby, making research repeatable (Yin, 2009). It contains field procedures, such as used instruments (e.g. questionnaires) and data collection. The interviews were semi-structured and the questionnaire mainly consisted of open questions. Most of the questions aimed to identify the relevant drivers and resistors. One example is, that the interviewees were asked, what their motivation was to start a specific project. This question aimed to identify the intrinsic and extrinsic motivation to start SCCs. Thereby, the parties were free to mention more than one collaboration project in which they participated or in which they planned to participate but that did not start. An 
interview guide was sent around one week before the interview to give the participants sufficient time for preparation. A report was made of each interview and was sent back to the interviewees for verification to confirm that the interpretations were consistent with respondents' interpretations and strengthens validity (Yin, 2009). After a detailed case study write-up for each case, the data were analysed using cross-case analysis. The key to a good cross-case comparison is looking at the data in many divergent ways. Eisenhardt (1989) discusses three cross-case tactics. One tactic is to select categories and then look for within-group similarities coupled with intergroup differences.

Dimensions can be suggested by literature or can simply be chosen by the researcher. A second tactic is to group the cases and then list the similarities and differences between them. And, finally, data can be divided by data source. The first two approaches were used, because this enables an analysis of the elements as identified in literature as well as on new elements identified in practice and, thereby, enhance the probability that the findings, which may exist in the data, are captured. After comparing the drivers and resistors mentioned in the interviews with the general factors of the conceptual framework, the factors were analysed by category and by party. The sample consisted of the companies of the Dutch FMCG industry that were participating in a logistics competition in the Netherlands. Of the 26 participating parties, 20 accepted the interview request, which is equal to a response rate of $77 \%$. Seven manufacturers, six LSPs and seven retailers participated and the interviews were mainly conducted face to face. Nevertheless, due to time constraints three interviews could only be conducted via telephone. In total 20 different SCC projects were mentioned. Most of these projects were named by more than one interviewee. Therefore, differences and similarities of drivers and resistors identified from different perspectives for one specific project could be investigated.

\section{Results}

In this section the cross-case analysis is presented. The factors reported in the cases are included in the framework as either another example of existing general factors or as additional general factors. Results and further findings are discussed by category.

\subsection{Benefits}

Table 1 shows all benefits mentioned by each party - the LSP, the manufacturer (MA) and the retailer (RE) - and also specifies whether the factor was mentioned by a party who actually started the SCC (C) or not (NC). All mentioned benefits were identified as, sometimes new, examples of the general factors in the conceptual framework (see Appendix B "Allocation Benefits").

In total, the most often mentioned benefit is "cost reduction", which falls in the general factor "efficiency improvements". Cost reduction was mentioned as an intrinsic motivation factor for 14 collaboration projects. Half of it was mentioned by the LSPs. Moreover, by looking at all the other benefits of the LSPs, it is obvious, that the LSPs were mainly driven by efficiency improvement factors. The majority of the mentioned benefits are factors belonging to the general factor "efficiency improvements". The second most often mentioned benefit is sustainability improvement. Moreover, it has been observed that nearly half of the mentioned benefits were named by retailers.

Except of three factors, the benefits were mentioned by parties that actually started the SCC. Moreover, some parties also started SCC projects without any intrinsic motivation. 
Table 1: Allocation of the benefit factors

\begin{tabular}{|c|c|c|c|c|c|c|}
\hline General factors & Factors & LSP & MA & RE & C & NC \\
\hline Customer improvements & Customer satisfaction & 1 & 1 & & 2 & \\
\hline \multirow[t]{12}{*}{ Efficiency improvements } & Cost reduction & 7 & 3 & 4 & 13 & 1 \\
\hline & Time reduction & 1 & & 4 & 4 & 1 \\
\hline & Faster unloading process & & & 1 & & 1 \\
\hline & Efficiency improvement & 2 & 1 & 3 & 6 & \\
\hline & Lower costs in inbound process & & & 1 & 1 & \\
\hline & $\begin{array}{l}\text { Lower contract costs with supplier because } \\
\text { of time savings }\end{array}$ & & & 1 & 1 & \\
\hline & Gain total benefit out of the collaboration & & & 1 & 1 & \\
\hline & $\begin{array}{l}\text { Surcharge reduction for customers for } \\
\text { negotiating other time slots with retailer }\end{array}$ & 1 & & & 1 & \\
\hline & Reduced incoming goods full time employees & & & 1 & 1 & \\
\hline & Monetary issue & & & 1 & 1 & \\
\hline & Quality issue & & & 1 & 1 & \\
\hline & $\begin{array}{l}\text { Optimal capacity planning and dock capacity } \\
\text { through spread of arrival times of trucks }\end{array}$ & & & 1 & 1 & \\
\hline \multirow[t]{2}{*}{ Enhanced enablers } & Stronger partnership & 1 & & & 1 & \\
\hline & Enhancing relationship towards customer & & 1 & & 1 & \\
\hline \multirow[t]{2}{*}{ Image improvements } & Image improvement & & 1 & & 1 & \\
\hline & Professionalism & & 1 & & 1 & \\
\hline \multirow[t]{2}{*}{ Sustainability improvements } & $\mathrm{CO}_{2}$-reduction & 1 & 2 & 3 & 6 & \\
\hline & Sustainability & & 1 & & 1 & \\
\hline \multirow[t]{2}{*}{ Technology improvements } & Offers new possibilities/technologies & & & 1 & 1 & \\
\hline & Using technology also for other customers & 1 & & & 1 & \\
\hline
\end{tabular}

\subsection{Forces}

Also for the forces all identified factors (see Table 2) could be assigned to already existing general factors (see Appendix B "Allocation Forces").

In contrast to the intrinsic motivation, only a few extrinsic motivation factors were mentioned. For a few projects the parties mentioned that they were forced by other supply chain parties to start a specific project. The majority was forced by the retailers to start SCCs. Three LSPs and six manufacturers were forced by retailers to for example use specific software. Furthermore, one LSP was forced by a manufacturer to start a SCC.

All projects, where the retailer forced the LSP and/or the manufacturer to join the collaboration, started, although this was the only mentioned motivating factor for the parties to start the SCC project and next to it only resistors were named. In contrast to that, the SCC project, which was initiated by the manufacturer, did not start.

Table 2: Allocation of the force factors

\begin{tabular}{|c|c|c|c|c|c|c|}
\hline General factors & Factors & LSP & MA & RE & C & NC \\
\hline \multirow[t]{2}{*}{ Forced by other parties } & Forced by retailer & 3 & 5 & & 8 & \\
\hline & Demanded by manufacturer & 1 & & & & 1 \\
\hline
\end{tabular}

\subsection{Enablers and Barriers}

In contrast to the other categories, not all identified factors for the category "enablers/barriers" could be assigned to existing general factors. Several interviewees mentioned that talking about money (costs and gains) in the first meeting leads to rough negotiations that have resulted, in some cases, in not starting the SCC. For this factor no academic evidence has been found and, hence, an additional general factor was added, "presence of neglecting money in the first meeting", if it is an 
enabler, and "lack of neglecting money in the first meeting", otherwise. All other identified factors provide new examples for already existing general factors (see Appendix B "Allocation Enablers/Barriers").

"Organizational compatibility" and "transparency" are the most often mentioned factors. Both factors seem to be relevant for the majority of the SCC projects. This is followed by the enablers "interdependence" (17 times mentioned) and "trust" (16 times mentioned). In contrast to the enablers, more variety exists in the barriers. High investments for starting a SCC and a lack of compatibility seem to be the most relevant barriers for the parties in practice. Moreover, exclusively retailers mentioned the lack of benefits and the lack of fair gain sharing as another important barrier. Further, a good relationship to the contact person and the neglection of money in the first meeting seem to be more important barriers for the retailers and the manufacturers. In total, the majority of the factors were either mentioned as an enabler for a specific SCC or as a barrier.

By looking at the difference between collaboration and non-collaboration factors, it has been observed that the barrier "upfront investments" was often mentioned as a barrier for SCCs which did not start in the end.

Table 3: Allocation of the enabler/barrier factors

\begin{tabular}{|c|c|c|c|c|c|c|c|}
\hline General factors & Enablers/Barriers & Factors & LSP & MA & RE & $\mathbf{C}$ & NC \\
\hline \multirow[t]{2}{*}{$\begin{array}{l}\text { Presence of absence } \\
\text { of barriers }\end{array}$} & $\begin{array}{l}\text { Presence of } \\
\text { absence of } \\
\text { barriers }\end{array}$ & $\begin{array}{l}\text { Compliance } \\
\text { No legal barriers }\end{array}$ & 1 & 1 & & $\begin{array}{l}1 \\
1\end{array}$ & \\
\hline & $\begin{array}{l}\text { Lack of absence of } \\
\text { barriers }\end{array}$ & $\begin{array}{l}\text { Horizontal collaboration difficult } \\
\text { Legal barriers } \\
\text { Other projects have higher priorities }\end{array}$ & 2 & $\begin{array}{l}1 \\
1\end{array}$ & 1 & $\begin{array}{l}1 \\
3 \\
1\end{array}$ & \\
\hline $\begin{array}{l}\text { Presence of absence } \\
\text { of costs }\end{array}$ & $\begin{array}{l}\text { Lack of absence of } \\
\text { costs }\end{array}$ & $\begin{array}{l}\text { High investments in technology } \\
\text { Increased costs } \\
\text { Upfront investments } \\
\text { Time windows lead to higher costs } \\
\text { due to inflexibility }\end{array}$ & $\begin{array}{l}2 \\
2 \\
1 \\
1\end{array}$ & 3 & 2 & $\begin{array}{l}3 \\
2 \\
3 \\
1\end{array}$ & $\begin{array}{l}1 \\
4\end{array}$ \\
\hline $\begin{array}{l}\text { Presence of } \\
\text { commitment and } \\
\text { support }\end{array}$ & $\begin{array}{l}\text { Presence of } \\
\text { commitment and } \\
\text { support }\end{array}$ & Commitment & 2 & 1 & 4 & 7 & \\
\hline \multirow[t]{2}{*}{$\begin{array}{l}\text { Presence of } \\
\text { communication }\end{array}$} & $\begin{array}{l}\text { Presence of } \\
\text { communication }\end{array}$ & $\begin{array}{l}\text { Information sharing } \\
\text { Information technology }\end{array}$ & $\begin{array}{l}1 \\
3\end{array}$ & $\begin{array}{l}1 \\
6\end{array}$ & $\begin{array}{l}2 \\
5\end{array}$ & $\begin{array}{c}4 \\
14\end{array}$ & \\
\hline & $\begin{array}{l}\text { Lack of } \\
\text { communication }\end{array}$ & $\begin{array}{l}\text { Communication within triangular } \\
\text { relationships is lacking, because the } \\
\text { communication between LSP and } \\
\text { retailer is not existing } \\
\text { Connecting different integrated } \\
\text { device technology (IDT) systems is } \\
\text { very difficult and complex } \\
\text { Insufficient communication at } \\
\text { internal retailer side } \\
\text { Only old WMS available } \\
\text { Sharing confidential information } \\
\text { within vertical SCC is very difficult } \\
\text { Very complex information and } \\
\text { communication technology (ICT) } \\
\text { system }\end{array}$ & 1 & 1 & 2 & $\begin{array}{l}1 \\
1 \\
1\end{array}$ & \\
\hline $\begin{array}{l}\text { Presence of } \\
\text { compatibility }\end{array}$ & $\begin{array}{l}\text { Presence of } \\
\text { compatibility }\end{array}$ & $\begin{array}{l}\text { Common/clear goals } \\
\text { Holding end-customer central } \\
\text { (common goal) } \\
\text { Organizational compatibility } \\
\text { Shared values } \\
\text { Strategic fit }\end{array}$ & $\begin{array}{l}2 \\
1\end{array}$ & $\begin{array}{l}7 \\
1 \\
1\end{array}$ & 6 & $\begin{array}{c}18 \\
1 \\
1\end{array}$ & \\
\hline
\end{tabular}


Table 3 (continued)

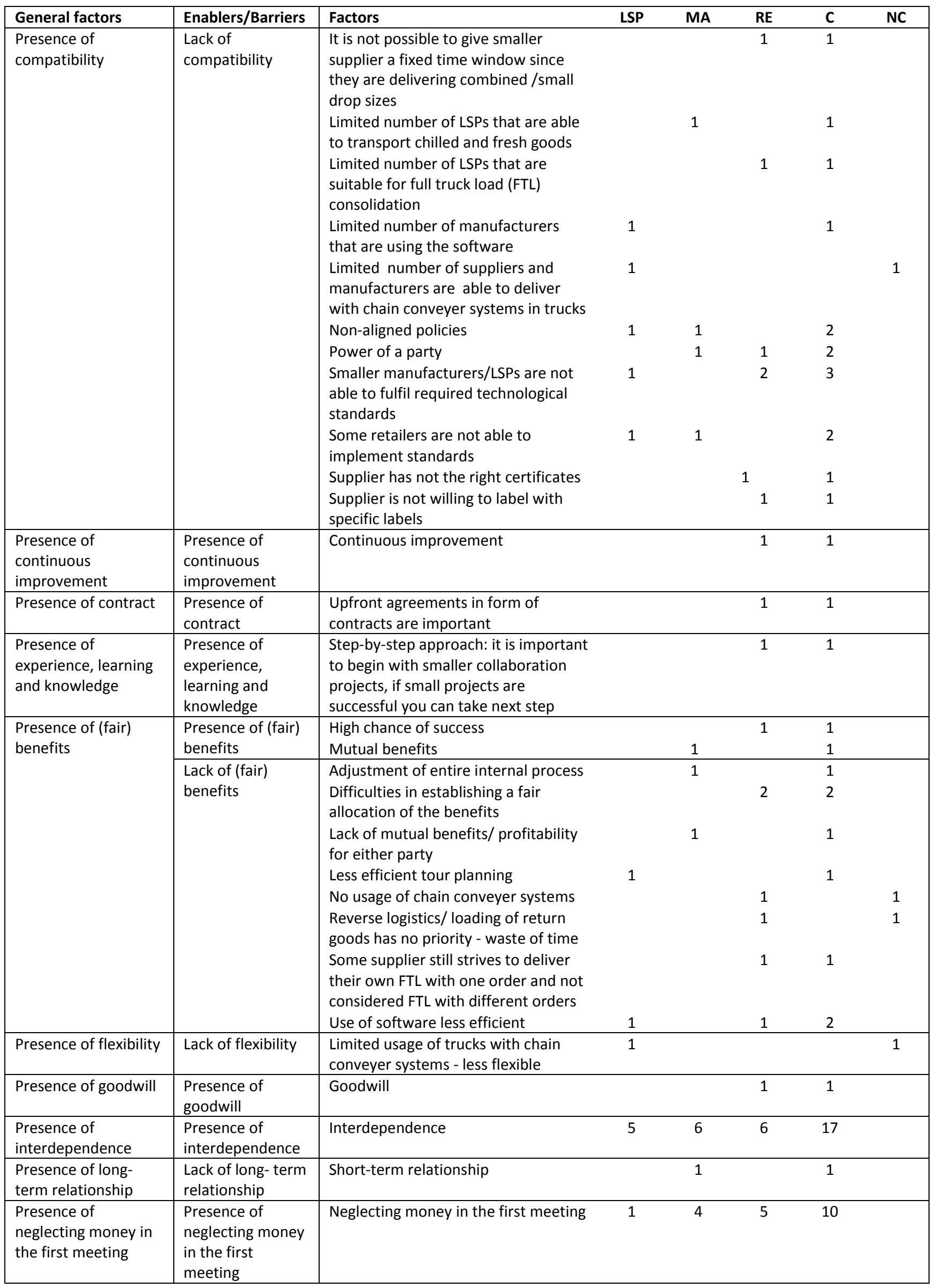


Table 3 (continued)

\begin{tabular}{|c|c|c|c|c|c|c|c|}
\hline General factors & Enablers/Barriers & Factors & LSP & MA & RE & C & NC \\
\hline $\begin{array}{l}\text { Presence of } \\
\text { neglecting money in } \\
\text { the first meeting }\end{array}$ & $\begin{array}{l}\text { Lack of neglecting } \\
\text { money in the first } \\
\text { meeting }\end{array}$ & $\begin{array}{l}\text { Fair gain sharing always discussion if } \\
\text { money is involved } \\
\text { Speaking about gain sharing very } \\
\text { complex }\end{array}$ & 1 & 1 & & 1 & \\
\hline $\begin{array}{l}\text { Presence of partner } \\
\text { contribution }\end{array}$ & $\begin{array}{l}\text { Presence of } \\
\text { partner } \\
\text { contribution }\end{array}$ & Contribution of other parties & 1 & & & 1 & \\
\hline $\begin{array}{l}\text { Presence of } \\
\text { resources }\end{array}$ & Lack of resources & $\begin{array}{l}\text { A lot of work required for } \\
\text { implementation } \\
\text { No capacity of manpower to start SCC } \\
\text { Not enough time and energy }\end{array}$ & 1 & & $\begin{array}{l}1 \\
2\end{array}$ & $\begin{array}{l}1 \\
1 \\
2\end{array}$ & 1 \\
\hline \multirow[t]{2}{*}{$\begin{array}{l}\text { Presence of right } \\
\text { contact person }\end{array}$} & $\begin{array}{l}\text { Presence of right } \\
\text { contact person }\end{array}$ & Relation to contact person & 1 & 4 & 6 & 11 & \\
\hline & $\begin{array}{l}\text { Lack of right } \\
\text { contact person }\end{array}$ & $\begin{array}{l}\text { Commercial vs. logistics } \\
\text { SCM vs. commercial (different ways } \\
\text { of thinking) } \\
\text { Wrong contact person }\end{array}$ & & $\begin{array}{l}1 \\
1\end{array}$ & $\begin{array}{l}1 \\
1 \\
\end{array}$ & $\begin{array}{l}1 \\
2 \\
1\end{array}$ & \\
\hline Presence of time & Presence of time & $\begin{array}{l}\text { Factor time: start the SCC to the right } \\
\text { time }\end{array}$ & & & 1 & 1 & \\
\hline \multirow[t]{2}{*}{$\begin{array}{l}\text { Presence of } \\
\text { transparency and } \\
\text { openness }\end{array}$} & $\begin{array}{l}\text { Presence of } \\
\text { transparency and } \\
\text { openness }\end{array}$ & $\begin{array}{l}\text { Honesty } \\
\text { Openness } \\
\text { Open-minded } \\
\text { Transparency }\end{array}$ & 1 & 1 & $\begin{array}{l}1 \\
1 \\
7\end{array}$ & $\begin{array}{c}1 \\
2 \\
1 \\
18\end{array}$ & \\
\hline & $\begin{array}{l}\text { Lack of } \\
\text { transparency and } \\
\text { openness }\end{array}$ & Lack of transparency & & 1 & & 1 & \\
\hline \multirow[t]{2}{*}{ Presence of trust } & Presence of trust & Trust & 4 & 5 & 7 & 16 & \\
\hline & Lack of trust & Lack of trust & & & 1 & 1 & \\
\hline $\begin{array}{l}\text { Presence of } \\
\text { willingness to change }\end{array}$ & $\begin{array}{l}\text { Presence of } \\
\text { willingness to } \\
\text { change }\end{array}$ & Willingness and drive to change & & 1 & & 1 & \\
\hline
\end{tabular}

\subsection{Risks}

The identified risks (Table 4) could all be assigned to already existing general factors as can be validated in Appendix B "Allocation Risks".

Only a few risks were mentioned by the interviewed parties and the most often mentioned risk is dependency. The parties often stated that dependency combined with short-term contracts (which are common in this industry) results in high risks. Moreover, most of the risks were identified by retailers and only retailers mentioned risks belonging to the general factor "uncertainty of performance problems".

All SCC projects, where risks were mentioned, also started in the end. 
Table 4: Allocation of the risks factors

\begin{tabular}{|c|c|c|c|c|c|c|}
\hline General factors & Factors & LSP & MA & RE & C & NC \\
\hline \multirow[t]{2}{*}{ Uncertainty of additional costs } & Costs are the main risk & & 1 & & 1 & \\
\hline & $\begin{array}{l}\text { Additional costs related to coordination and } \\
\text { controlling the collaborative relationship }\end{array}$ & & & 1 & 1 & \\
\hline $\begin{array}{l}\text { Uncertainty of change of key } \\
\text { personnel }\end{array}$ & $\begin{array}{l}\text { Risk, if one party involved terminates } \\
\text { relation within the project }\end{array}$ & & 1 & 2 & 3 & \\
\hline \multirow[t]{2}{*}{ Uncertainty of high dependency } & $\begin{array}{l}\text { Contract uncertainty; parties are mutually } \\
\text { dependent }\end{array}$ & & 2 & 2 & 4 & \\
\hline & Dependency & 2 & 2 & 2 & 6 & \\
\hline \multirow[t]{2}{*}{ Uncertainty of losing transparency } & $\begin{array}{l}\text { Danger of commercial usage of confidential } \\
\text { information }\end{array}$ & 1 & & & 1 & \\
\hline & Uncertainty of losing transparency & & 1 & & 1 & \\
\hline \multirow{4}{*}{$\begin{array}{l}\text { Uncertainty of performance } \\
\text { problems }\end{array}$} & Data reliability & & & 1 & 1 & \\
\hline & Quality performance problems & & & 1 & 1 & \\
\hline & Uncertainty of outcome & & & 1 & 1 & \\
\hline & $10-15 \%$ error rates of incoming goods & & & 1 & 1 & \\
\hline
\end{tabular}

\section{Discussion and Conclusions}

In the following, first, the results of the cross-case analysis are discussed in detail. Next, the contribution to the SCM literature and implications to SCM practice are outlined. In the end limitations and future research areas are discussed.

\subsection{Result Discussion}

In total, it has been observed that the framework is complete for the categories "benefits", "forces" and "risks". Only the category "enablers/barriers" missed one general factor. In the Dutch FMCG industry supply chain actors perceive that it is difficult to talk about money (costs and gains) in the first meeting. The interviewees even mentioned that talking about money (costs and gains) lead to rough negotiations, which have resulted, in some cases, in not starting the SCC. This has not been mentioned in the academic literature yet. Many articles already discussed the problem with sharing the gain in such a way that everybody is satisfied (e.g. Cruijssen et al., 2007), but it has not been mentioned that this is especially a problem in the first meeting. After adding an additional general factor, which is called "presence of neglecting money in the first meeting", if it is an enabler, and "lack of neglecting money in the first meeting", if it is a barrier, the framework is complete for all categories.

\subsubsection{Benefits}

In the Dutch FMCG industry the main intrinsic motivation factor is to reduce the costs. This factor has been mentioned as an important factor for parties to start a SCC in literature as well. Cruijssen et al. (2007) identify cost reduction as an important motivation factor for parties to start a SCC in the transportation and logistics industry. The same holds for the construction and the chemical industry (Akintoye et al., 2000; Visser, 2010). Sustainable improvement issues are also important motivation factors to start a SCC. In this context, the dominant factor is $\mathrm{CO}_{2}$-reduction. According to de Kok et al. (2015), in the FMCG industry the retailers demand high-frequency shipments to their distribution centers and the truck utilization efficiency is low. Therefore, it is reasonable that sustainability improvement, especially $\mathrm{CO}_{2}$-reduction, is an often-named intrinsic motivation factor. Another interesting finding is that the LSPs in the FMCG industry were mainly driven by efficiency improvement factors; sustainability improvement seems to be less relevant for the LSPs. This is in line with the literature review from Cruijssen et al. (2007), where the LSP perspective is observed in the transportation and logistics sector. Further, it could be detected that the majority of the mentioned benefits were named by the retailers, which indicates that retailers are highly intrinsically 
motivated. Finally, it has been identified that some parties also started a project without mentioning any benefits. In the majority of these cases, forces instead of benefits have been mentioned.

\subsubsection{Forces}

In the interviews exclusively manufacturers and LSPs mentioned extrinsic motivation factors to start SCCs. This confirms the assumption that retailers are highly intrinsically motivated. The finding contradicts with what has been identified by Walker et al. (2008). In their research, the authors identify important drivers and resistors for retailers and manufacturers for starting a green SCM initiative. In this context, the retailers were not exclusively intrinsically motivated, but also often forced to start the green collaboration. However, retailers in the FMCG industry seem to be exclusively intrinsically motivated. In addition, retailers are the most powerful party in the FMCG supply chain. They forced manufacturers and/or LSPs to start a specific project. This is in line with the research by Adolfsson and Solarz (2005). They investigate relationships between suppliers and a retailer in the Swedish FMCG industry. Adolfsson and Solarz (2005) outline that the retailer has a power position in the Swedish FMCG industry and that the suppliers are highly influenced by the retailers.

\subsubsection{Enablers/Barriers}

The most often mentioned enablers were "organisational compatibility" and "transparency" followed by the enablers "trust" and "interdependence". In literature it is often mentioned that trust and commitment are the most important enablers for starting SCCs (e.g. Ahmad and Ullah, 2013). For the parties of the Dutch FMCG industry organisational compatibility and transparency seem to be more important. In contrast to the enablers, for the barriers a higher variety has been identified. This indicates that the barriers are more individual and, therefore, highly dependent on the party and the specific situation. For the parties of the Dutch FMCG industry one main barrier to start SCCs and in the end also the main reasons for not collaborating were the upfront investments. This is in line with prior research. Min et al. (2005) point out that financial resources have to be available before starting collaborations. Another very important barrier for the parties of the Dutch FMCG industry was the lack of compatibility. Again, this is in line with former literature. The majority of the papers discussing barriers to start a SCC also named lack of compatibility as a barrier. In total, it has been observed that the majority of the factors were either mentioned as an enabler or as a barrier for a SCC. However, a few parties also mentioned factors as enablers and barriers for a project. In these cases, the parties mentioned the general importance of an enabler to start a specific SCC. However, for the specific project the factor has been mentioned as a barrier. The majority of these factors can be assigned to the project, where the retailer forced parties to use specific software. In these cases, the manufacturers and LSPs outlined the general importance of organizational compatibility, but simultaneously mentioned the lack of organizational compatibility for this specific project.

\subsubsection{Risks}

In total, only a few risks have been mentioned by the participants. In literature also only a fairly limited number of papers discuss potential risks of SCCs. In total, only five papers (Cruijssen et al., 2007; Landeros et al., 1995; Maloni and Benton, 1997; Niederkofler, 1996; Visser, 2010) investigate risks for starting SCCS. Moreover, it has been identified that in all cases the SCC projects started, which might indicate that risks are not the main reason for rejecting a SCC project. The majority of the participants mentioned the high dependency as an important risk. This has been mentioned as an important risk for SCCs by Visser (2010) as well.

\subsubsection{Further Findings}

To evaluate a potential SCC, it is important for parties to be aware of all potential factors. However, it is not necessarily the case that all (general) factors, except from the category "enablers/barriers", are 
relevant in every SCC; it depends on the party, its industry and the type of SCC. Through the interviews differences between the parties but also between different types of SCCs have been identified. An example for a special factor for one type of SCC is the following. Four LSPs wanted to start a horizontal SCC. As a barrier "legal barriers" has been mentioned. This is a specific barrier for a horizontal SCC. The problem is that the European Commission competition law prohibits any agreements between the parties that are restrictive of competition like price agreements etc. (Cruijssen et al., 2007). Therefore, competition might be restricted if the parties involved in the horizontal collaboration exceed together a certain market share. According to the European Commission (2012) the current rule is that the parties are not allowed to exceed a market share of 20 $\%$. Referring to the literature, for example Cruijssen et al. (2007) also mention a special factor. They investigated a horizontal SCC in the transportation and logistics industry. In their paper, the authors identified "risk of losing clientele to competitors" as an important risk. This risk is relevant for LSPs in the transport and logistics industry when they are participating in a horizontal SCC. Moreover, it is possible that even a whole category is not relevant for a party. The findings showed that especially when parties are forced to collaborate it is often the case that the intrinsic motivation to start a SCC is absent.

\subsection{Contribution to the SCM literature}

Although prior research widely discussed potential drivers and resistors, until now a study including all drivers and resistors is missing. Moreover, some kind of incompleteness existed; factors mentioned in one paper for a specific category are not mentioned in other papers. In addition to that, in this research two kinds of ambiguity have been identified. The first kind of ambiguity is that some terms are used for different categories and that no unique term for the identified categories exists. The second kind of ambiguity is that factors are assigned to more than one category. In this paper, a structured framework with a consistent terminology and definitions has been developed, which enriches the SCM literature with an extensive specification of all potential drivers and resistors for starting SCCs. Moreover, in academic literature until now only dyadic relationships have been investigated. In contrast to that, the proposed framework has been tested in a complex environment where also three or more independent parties were involved in a SCC, which makes the framework complete for different types of collaborations.

\subsection{Implications to SCM practice}

Parties that consider starting a SCC will benefit from this study. The study supports parties to better evaluate the considered SCC and, thus, increase the probability that SCCs which cannot be successful won't start. The introduced framework provides a checklist containing all potential general factors of drivers and resistors, which have to be taken into consideration before starting a SCC. Moreover, through a clear distinction between the four different categories, consistent definitions and explanations of the influence of these categories on the SCC, the understanding of the different categories is increased. As stated in Section 1, one reason for the failure of SCCs might be the fact that factors are unknown to or misunderstood by the parties. The structured and complete framework prevents this. To identify all relevant drivers and resisters for the considered SCC, every party should evaluate all (general) factors of the four categories regarding their relevance. Based on the identified factors the decision to start the SCC can be made by evaluating whether the factors that have a positive influence on the relationship overweight the negative ones. 


\subsection{Limitations and future research}

Despite the contributions this research made, there are some limitations that can be considered as areas for further research. In the study only a limited set of cases has been used and the sample of the study only consisted of parties from one industry in the Netherlands. Further research should include other geographical areas and/or a broader range of industries. As stated previously, the framework provides the first complete overview not only for dyadic relationships, but also for SCCS with more than two parties. Nevertheless, the sample size for each type of relationship was very small. To build a framework for a specific type of SCC, it is necessary to conduct more interviews with parties participating in this special kind of relationship. Furthermore, the framework should be tested in practice to discover whether it can actually close the gap between theory and practice. Therefore, it is useful to interview parties which already participated in a failed SCC to investigate whether the SCC would not have been started or failure would have been prevented if all parties involved would have taken into account all factors included in the framework. Finally, this study only investigated which drivers and resistors factors are relevant for parties to start a SCC, but the importance of the factor has not been quantified for the specific party and collaboration. Quantifying the factors for each party can be beneficial and should also be considered in further research.

\section{References}

Adolfsson, M., Solarz, D. (2005), "Power Shift and Retailer Value in the Swedish FMCG Industry", Thesis, Linköpings Universitet.

Ahmad, S., Ullah, A. (2013), "Driving Forces of Collaboration in Supply Chain: A Review", Interdisciplinary Journal of Contemporary Research in Business, Vol. 5 No. 7, pp. 39-69.

Akintoye, A., McIntosh, G., Fitzgerald, E. (2000), "A survey of supply chain collaboration and management in the UK construction industry", European Journal of Purchasing \& Supply Management, Vol. 6, pp. 159-168.

Anbanandam, R., Banwet Ravi Shankar, D.K. (2011), "Evaluation of supply chain collaboration: a case of apparel retail industry in India", International Journal of Productivity and Performance Management, Vol. 60 No. 2, pp. 82-98.

Autry, C.W. (2011), "Collaboration in Supply Chain: Getting Things Done Beyond the Four Walls", Supply Chain Management Review, available at:

http://www.scmr.com/article/collaboration_in_the_supply_chain_getting_things_done_beyond_the _four_walls/ (accessed 20 June 2016).

Barrat, M. (2004), "Understanding the meaning of collaboration in the supply chain", Supply Chain Management: An International Journal, Vol. 9 No. 1, pp. 30-42.

Beach, R., Webster, M., Campbell, K.M. (2005), “An evaluation of partnership development in the construction industry", International Journal of Project Management, Vol. 23, pp. 611-621.

Boddy, D., McBeth, D., Wagner, B. (2000), “Implementing Collaboration between Organizations: An Empirical Study of Supply Chain Partnering", Journal of Management Studies, Vol. 37 No.7, pp. 10031017.

Brinkerhoff, J.M. (2002), “Assessing and improving partnership relationships and outcomes: a proposed framework", Evaluation and Program Planning 25, pp. 215-231. 
Cao, M., Zhang, Q. (2011), "Supply chain collaboration: Impact on collaborative advantage and firm performance", Journal of Operations Management, Vol. 29, pp. 163-180.

Cruijssen, F., Dullaert, W., Fleuren, H. (2007), "Horizontal Cooperation in Transport and Logistics: A Literature Review", Transportation Journal, Vol. 46 No. 3, pp. 22-39.

Daugherty, P.J., Richey, R.G., Roath, A.S., Min, S., Chen, H., Arndt, A.D., Genchev, S.E. (2006), "Is collaboration paying off for firms?", Business Horizons, Vol. 49, pp. 61-70.

De Kok, A.G., van Dalen, J., van Hillegersberg, J. (eds.) (2015), Cross-Chain Collaboration in the Fast Moving Consumer Goods Supply Chain, Eindhoven University of Technology, ISBN: 978-90-386-38140 .

De Leeuw, S., Fransoo, J. (2009), "Drivers of close supply chain collaboration: one size fits all?", International Journal of Operations\& Production Management, Vol. 29 No. 7, pp. 720-739.

Eisenhardt, K.M. (1989), "Building Theories from Case Study Research", The Academy of Management Review, Vol.14, No.4, pp. 532-550.

Ellram, L.M. (1995), "A Managerial Guideline for the Development and Implementation of Purchasing Partnerships", National Association of Purchasing Management, pp. 10-16.

European Commission (2012), "Horizontal cooperation agreements", available at: http://ec.europa.eu/competition/antitrust/legislation/horizontal.html (accessed 02 March 2017)

Evans, J. (2012), "Managing Assumptions, Risks and Impediments in Strategic Planning", available at: http://blog.vistage.com/business-strategy-and-management/managing-assumptions-risks-andimpediments-in-strategic-planning/ (accessed 10 January 2016).

Fawcett, S.E., Magnan, G.M., McCarter, M. (2008a), "Benefits, barriers, and bridges to effective supply chain management", Supply Chain Management: An International Journal, Vol. 13 No.1, pp. 35-48.

Fawcett, S.E., Magnan, G.M., McCarter, M. (2008b), “A Three-Stage Implementation Model for Supply Chain Collaboration”, Journal of Business Logistics, Vol. 29 No. 1, pp. 93-112.

Fuller, C.W., Vassie, L.H. (2002), "Assessing the maturity and alignment of cultures in partnership arrangements", Employee Relations, Vol. 24 No. 5, pp. 540-555.

Heikkilä, J. (2002), "From supply to demand chain management: efficiency and customer satisfaction", Journal of Operations Management 20, pp. 747-767.

Horvath, L. (2001), "Collaboration: the key to value creation in supply chain management", Supply Chain Management: An International Journal, Vol. 9 No. 2, pp. 1-20.

Jung, V., Peeters, M., Vredeveld, T. (2017), "Drivers and Resistors for Supply Chain Collaboration", in Fink, A, Fügenschuh, A, Geiger, MJ, Operations Research Proceedings 2016 proceedings of the Annual International Conference of the German Operations Research Society in Hamburg, Germany, 2016, Springer Verlag, Vienna.

Kim, D.-Y., Kumar, V., Kumar, U. (2010), "Performance assessment framework for supply chain partnership", Supply Chain Management: An International Journal, Vol. 15 No. 3, pp. 187-195.

Lambert, D.M., Emmelhainz, M.A., Gardner, J.T. (1996), “Developing and Implementing Supply Chain Partnerships", The International Journal of Logistics Management, Vol. 7 No. 2, pp. 1-17. 
Lambert, D.M., Emmelhainz, M.A., Gardner, J.T. (1999), "Building Successful Logistics Partnerships", Journal of Business Logistics, Vol. 20 No.1, pp. 165-181.

Landeros, R., Reck, R., Plank, R.E. (1995), “Maintaining Buyer-Supplier Partnerships”, International Journal of Purchasing and Materials Management, pp. 2-12.

Maheshwari, B., Kumar, V., Kumar, U. (2006), "Optimizing success in supply chain partnerships", Journal of Enterprise Information Management, Vol. 19 No.3, pp. 277-291.

Maloni, M.J., Benton, W.C. (1997), "Supply chain partnerships: Opportunities for operations research", European Journal of Operational Research, Vol. 101, pp. 419-429.

Min, S., Roath, A.S., Daugherty, P.J., Genchev, S.E., Chen, H., Arndt, A.D., Richey, R.G. (2005), "Supply chain collaboration: What's happening?", The International Journal of Logistics Management, Vol. 16 No. 2, pp. 237-256.

Min, H., Zhou, G. (2002), "Supply chain modelling: past, present and future", Computers \& Industrial Engineering 43, pp. 231-249.

Mohr, J.J., Spekman, R.E. (1994), "Characteristics of Partnership Success: Partnership Attributes, Communication Behavior, and Conflict Resolution Techniques", Strategic Management Journal, Vol. 15, pp. 135-152.

Niederkofler, M. (1991), "The Evolution of Strategic Alliances: Opportunities for Managerial Influence", Journal of Business Venturing, Vol. 6, pp. 237-257.

Perry, M., Sohal, A.S. (2001), "Effective quick response practices in a supply chain partnership: An Australian case study", International Journal of Operations \& Production Management, Vol. 21 No. 5/6, pp. 840-854.

Qu, S.Q., Dumay, J. (2011), "The qualitative research interview", Qualitative Research in Accounting \& Management, Vol. 8 No. 3, pp. 238-264.

Reniers, G., Dullart, W., Visser, L. (2010), "Empirically based development of a framework for advancing and stimulating collaboration in the chemical industry (ASC): creating sustainable chemical industrial parks", Journal of Cleaner Production, Vol. 18, pp. 1587-1597.

Richey Jr, R.G., Chen, H., Upreti, R., Fawcett, S.E., Adams, F.G. (2009), "The moderating role of barriers on the relationship between drivers to supply chain integration and firm performance", International Journal of Physical Distribution \& Logistics Management, Vol. 39 No. 10, pp. 826-840.

Riggin, L.J.C., Grasso, P.G., Westcott, M.L. (1992), “A Framework for Evaluating Housing and Community Development Partnership Projects", Public Administration Review, Vol. 52 No. 1, pp. 4046.

Ryu, I., So, S., Koo, C. (2009), "The role of partnership in supply chain performance", Industrial Management \& Data Systems, Vol. 109 No. 4, pp. 496-514.

Sabath, R.E., Fontanella, J. (2002), "The unfulfilled promise of supply chain collaboration", Supply Chain Management Review, Vol. 6 No.4, pp. 24-29.

Simatupang ,T.M., Sridharan, R. (2002), "The Collaborative Supply Chain", The International Journal of Logistics Management, Vol. 13 No. 1, pp. 15-30.

Visser, L.J. (2010), "Thresholds in Logistics Collaboration Decisions: A Study in the Chemical Industry". Dissertation, Tilburg University. 
Walker, H., Di Sisto, L., McBain, D. (2008), "Drivers and barriers to environmental supply chain management practices: Lessons from the public and private sectors", Journal of Purchasing \& Supply Management, Vol. 14, pp. 69-85.

Yin, R.K. (2009), Case Study Research: Design and Methods ( $4^{\text {th }}$ ed.), Sage Publications, Thousand Oaks, CA. 


\section{Appendix A}

\section{Complete Framework}

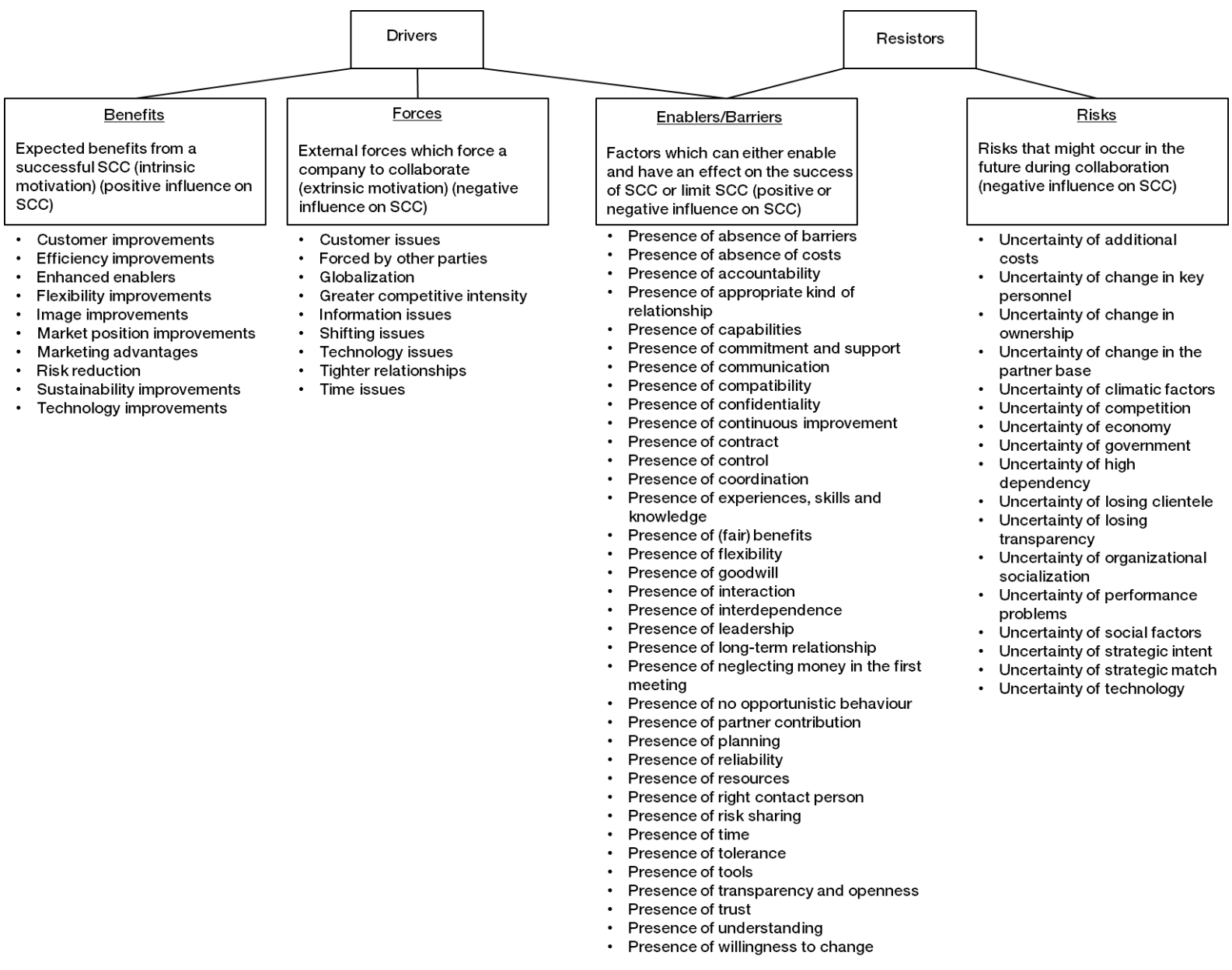

Figure 2: Complete framework 


\section{Appendix B}

\section{Allocation Benefits}

Table 5: Allocation benefits

\begin{tabular}{|c|c|c|}
\hline General Factor & Factor & Paper, Industry and Perspective \\
\hline \multirow{9}{*}{$\begin{array}{l}\text { Customer improvements: } \\
\text { Factors which indicate an } \\
\text { improvement that has a direct } \\
\text { effect on the customers like an } \\
\text { increased customer service }\end{array}$} & Customer satisfaction & $\begin{array}{l}\text { Fawcett et al. (2008a); Horvath (2001); } \\
\text { Min and Zhou (2002); }{ }^{[1]}, \text { FMCG } \\
\text { industry, manufacturer and LSP } \\
\text { perspective }\end{array}$ \\
\hline & Enhanced delivery performance & Fawcett et al. (2008b) \\
\hline & Focus on core competencies & $\begin{array}{l}\text { Visser (2010), chemical industry and } \\
\text { logistics outsourcing, shipper perspective }\end{array}$ \\
\hline & Improved customer service & $\begin{array}{l}\text { Ahmad and Ullah (2013); Akintoye et al. } \\
\text { (2000), construction industry, } \\
\text { manufacturer perspective; Beach et al. } \\
\text { (2005), construction industry, } \\
\text { manufacturer perspective; Cruijssen et } \\
\text { al. (2007), transport and logistics } \\
\text { industry, LSP perspective; Horvath } \\
\text { (2001); Lambert et al. (1996); Min et al. } \\
\text { (2005); Visser (2010), logistics } \\
\text { collaboration and outsourcing }\end{array}$ \\
\hline & Increased customer responsiveness & $\begin{array}{l}\text { Cruijssen et al. (2007), transport and } \\
\text { logistics industry, LSP perspective; } \\
\text { Fawcett et al. (2008a); Horvath (2001); } \\
\text { Kim et al. (2010), fast moving global } \\
\text { markets }\end{array}$ \\
\hline & Increased customer retention & Horvath (2001) \\
\hline & More consistent on time delivery & $\begin{array}{l}\text { Fawcett et al. (2008a); Kim et al. (2010), } \\
\text { fast moving global markets; Simatupang } \\
\text { and Sridharan (2002) }\end{array}$ \\
\hline & Reduced customer complaints & $\begin{array}{l}\text { Kim et al. (2010), fast moving global } \\
\text { markets }\end{array}$ \\
\hline & Specialization & $\begin{array}{l}\text { Cruijssen et al. (2007), transport and } \\
\text { logistics industry, LSP perspective }\end{array}$ \\
\hline \multirow{8}{*}{$\begin{array}{l}\text { Efficiency improvements: } \\
\text { Factors which indicate } \\
\text { improvements in how well } \\
\text { expended resources are utilized } \\
\text { e.g. cost reduction and time } \\
\text { reduction }\end{array}$} & Accelerated product delivery times & Horvath (2001) \\
\hline & $\begin{array}{l}\text { Allowed financial resources to be } \\
\text { concentrated on main stream businesses }\end{array}$ & $\begin{array}{l}\text { Visser (2010), logistics outsourcing, } \\
\text { shipper perspective }\end{array}$ \\
\hline & Backorder/Stock-out & $\begin{array}{l}\text { Kim et al. (2010), fast moving global } \\
\text { markets; Simatupang and Sridharan } \\
\text { (2002) }\end{array}$ \\
\hline & Benefits to the clients, suppliers & $\begin{array}{l}\text { Akintoye et al. (2000), construction } \\
\text { industry, manufacturer perspective }\end{array}$ \\
\hline & $\begin{array}{l}\text { Best value, which can be drawn out of a } \\
\text { project utilizing the specialist knowledge } \\
\text { and expertise of supplier }\end{array}$ & $\begin{array}{l}\text { Beach et al. (2005) construction industry, } \\
\text { manufacturer perspective }\end{array}$ \\
\hline & Better pricing & Min et al. (2005) \\
\hline & Coordination of process & Maloni and Benton (1997) \\
\hline & Closer link between demand/supply & $\begin{array}{l}\text { Akintoye et al. (2000), construction } \\
\text { industry, manufacturer perspective }\end{array}$ \\
\hline
\end{tabular}

${ }^{[1]} *$ refers to this paper 


\begin{tabular}{|c|c|c|}
\hline General Factor & Factor & Paper, Industry and Perspective \\
\hline \multirow[t]{26}{*}{$\begin{array}{l}\text { Efficiency improvements: } \\
\text { Factors which indicate } \\
\text { improvements in how well } \\
\text { expended resources are utilized } \\
\text { e.g. cost reduction and time } \\
\text { reduction }\end{array}$} & Cost reduction & $\begin{array}{l}\text { Akintoye et al. (2000), construction } \\
\text { industry, manufacturer perspective; } \\
\text { Cruijssen et al. (2007), transport and } \\
\text { logistics industry, LSP perspective; } \\
\text { Horvath (2001); Visser (2010), chemical } \\
\text { industry, logistics collaboration and } \\
\text { outsourcing, shipper perspective; Walker } \\
\text { et al. (2008); *, FMCG industry, LSP, } \\
\text { manufacturer and retailer perspective }\end{array}$ \\
\hline & $\begin{array}{l}\text { Decreased administrative and switching } \\
\text { effort }\end{array}$ & Maloni and Benton (1997) \\
\hline & Economies of scale in production & Ahmad and Ullah (2013) \\
\hline & Efficiency improvement & $\begin{array}{l}\text { Visser (2010), logistic outsourcing, } \\
\text { shipper perspective, }{ }^{*} \text {, FMCG industry, } \\
\text { LSP, manufacturer and retailer } \\
\text { perspective }\end{array}$ \\
\hline & Enhanced data capture & Maloni and Benton (1997) \\
\hline & Faster speed to market & $\begin{array}{l}\text { Cruijssen et al. (2007), transport and } \\
\text { logistics industry, LSP perspective }\end{array}$ \\
\hline & Faster unloading process & *, FMCG industry, retailer perspective \\
\hline & Fill rate & $\begin{array}{l}\text { Kim et al. (2010), fast moving global } \\
\text { markets }\end{array}$ \\
\hline & Firm productivity & Fawcett et al. (2008a) \\
\hline & $\begin{array}{l}\text { Gain total benefit out of the } \\
\text { collaboration }\end{array}$ & $*$, FMCG industry, retailer perspective \\
\hline & Gaining rapid access to the markets & Ahmad and Ullah (2013) \\
\hline & Improved asset utilization & $\begin{array}{l}\text { Ahmad and Ullah (2013); Fawcett et al. } \\
\text { (2008a); Fawcett et al. (2008b); Lambert } \\
\text { et al. (1996); Min and Zhou (2002) }\end{array}$ \\
\hline & Improved firm performance & Richey et al. (2009); Walker et al. (2008) \\
\hline & Improved operations & $\begin{array}{l}\text { Visser (2010), logistics outsourcing, } \\
\text { shipper perspective }\end{array}$ \\
\hline & Improved process oriented layout & Maloni and Benton (1997) \\
\hline & Improved quality & $\begin{array}{l}\text { Maloni and Benton (1997); Walker et al. } \\
(2008)\end{array}$ \\
\hline & Improved quality assurance & $\begin{array}{l}\text { Akintoye et al. (2000), construction } \\
\text { industry, manufacturer perspective }\end{array}$ \\
\hline & Improved sales & $\begin{array}{l}\text { Kim et al. (2010), fast moving global } \\
\text { markets; Min et al. (2005); Simatupang } \\
\text { and Sridharan (2002) }\end{array}$ \\
\hline & Increased cash-to-cash velocity & Fawcett et al. (2008b) \\
\hline & Increased cost competitiveness & Fawcett et al. (2008b) \\
\hline & Increased profitability & $\begin{array}{l}\text { Akintoye et al. (2000), construction } \\
\text { industry, manufacturer perspective }\end{array}$ \\
\hline & Increased profits & $\begin{array}{l}\text { Kim et al. (2010), fast moving global } \\
\text { markets; Lambert et al. (1996) }\end{array}$ \\
\hline & Investment related & $\begin{array}{l}\text { Visser (2010), chemical industry and } \\
\text { logistics outsourcing, shipper perspective }\end{array}$ \\
\hline & $\begin{array}{l}\text { Lower contract costs with supplier } \\
\text { because of time saving }\end{array}$ & $*$, FMCG industry, retailer perspective \\
\hline & Lower costs in inbound process & *, FMCG industry, retailer perspective \\
\hline & $\begin{array}{l}\text { More efficient product development } \\
\text { efforts }\end{array}$ & Horvath (2001) \\
\hline
\end{tabular}




\begin{tabular}{|c|c|c|}
\hline General Factor & Factor & Paper, Industry and Perspective \\
\hline \multirow{26}{*}{$\begin{array}{l}\text { Efficiency improvements: } \\
\text { Factors which indicate } \\
\text { improvements in how well } \\
\text { expended resources are utilized } \\
\text { e.g. cost reduction and time } \\
\text { reduction }\end{array}$} & $\begin{array}{l}\text { Optimal planning and dock capacity } \\
\text { through spread arrival times }\end{array}$ & *, FMCG industry, retailer perspective \\
\hline & $\begin{array}{l}\text { Outsourced area was major problem for } \\
\text { the party }\end{array}$ & $\begin{array}{l}\text { Visser (2010), logistics outsourcing, } \\
\text { shipper perspective }\end{array}$ \\
\hline & Overall improvement of distribution & $\begin{array}{l}\text { Visser (2010), logistics outsourcing, } \\
\text { shipper perspective }\end{array}$ \\
\hline & Project success & $\begin{array}{l}\text { Beach et al. (2005), construction } \\
\text { industry, manufacturer perspective }\end{array}$ \\
\hline & Quality issue & *, FMCG industry, retailer perspective \\
\hline & Quantity discount & Maloni and Benton (1997) \\
\hline & Reduced costs of used resources & $\begin{array}{l}\text { Kim et al. (2010), fast moving global } \\
\text { markets }\end{array}$ \\
\hline & Reduced distribution costs & $\begin{array}{l}\text { Horvath (2001); Kim et al. (2010), fast } \\
\text { moving global markets }\end{array}$ \\
\hline & Reduced handling costs & $\begin{array}{l}\text { Lambert et al. (1996); Reniers et al. } \\
\text { (2010), chemical industry, shipper } \\
\text { perspective }\end{array}$ \\
\hline & Reduced information costs & Lambert et al. (1996) \\
\hline & Reduced inventory costs & $\begin{array}{l}\text { Ahmad and Ullah (2013); Fawcett et al. } \\
\text { (2008a); Horvath (2001); Kim et al. } \\
\text { (2010), fast moving global markets; Min } \\
\text { et al. (2005); Reniers et al. (2010), } \\
\text { chemical industry, shipper perspective; } \\
\text { Simatupang and Sridharan (2002) }\end{array}$ \\
\hline & Reduced manufacturing costs & $\begin{array}{l}\text { Horvath (2001); Kim et al. (2010), fast } \\
\text { moving global markets }\end{array}$ \\
\hline & Reduced manufacturing lead times & $\begin{array}{l}\text { Kim et al. (2010), fast moving global } \\
\text { markets }\end{array}$ \\
\hline & Reduced overall product costs & $\begin{array}{l}\text { Fawcett et al. (2008a); Lambert et al. } \\
\text { (1996) }\end{array}$ \\
\hline & Reduced overall purchasing costs & Fawcett et al. (2008a) \\
\hline & Reduced packaging costs & Lambert et al. (1996) \\
\hline & Reduced (product) development costs & $\begin{array}{l}\text { Ahmad and Ullah (2013); Fawcett et al. } \\
\text { (2008a); Reniers et al. (2010), chemical } \\
\text { industry, shipper perspective }\end{array}$ \\
\hline & Reduced product innovation lead time & $\begin{array}{l}\text { Ahmad and Ullah (2013); Fawcett et al. } \\
\text { (2008a); Fawcett et al. (2008b) }\end{array}$ \\
\hline & Reduced transaction costs & $\begin{array}{l}\text { Maloni and Benton (1997); Visser (2010), } \\
\text { logistics collaboration, shipper } \\
\text { perspective }\end{array}$ \\
\hline & Reduced transportation costs & $\begin{array}{l}\text { Fawcett et al. (2008a); Horvath (2001); } \\
\text { Lambert et al. (1996); Reniers et al. } \\
\text { (2010), chemical industry, shipper } \\
\text { perspective }\end{array}$ \\
\hline & Reduced warehousing costs & Horvath (2001) \\
\hline & Reducing bureaucracy and paperwork & $\begin{array}{l}\text { Akintoye et al. (2000), construction } \\
\text { industry, manufacturer perspective }\end{array}$ \\
\hline & $\begin{array}{l}\text { Reducing incoming goods full time } \\
\text { employees }\end{array}$ & *, FMCG industry, retailer perspective \\
\hline & Reducing lost sales & Simatupang and Sridharan (2002) \\
\hline & Reducing markdowns & Simatupang and Sridharan (2002) \\
\hline & Reducing obsolete inventory & Simatupang and Sridharan (2002) \\
\hline
\end{tabular}




\begin{tabular}{|c|c|c|}
\hline General Factor & Factor & Paper, Industry and Perspective \\
\hline \multirow[t]{10}{*}{$\begin{array}{l}\text { Efficiency improvements: } \\
\text { Factors which indicate } \\
\text { improvements in how well } \\
\text { expended resources are utilized } \\
\text { e.g. cost reduction and time } \\
\text { reduction }\end{array}$} & Return on investment (ROI) & $\begin{array}{l}\text { Kim et al. (2010), fast moving global } \\
\text { markets; Min et al. (2005); Min and Zhou } \\
\text { (2002); Reniers et al. (2010), chemical } \\
\text { industry, shipper perspective; } \\
\text { Simatupang and Sridharan (2002) }\end{array}$ \\
\hline & Set-up time reduction & Maloni and Benton (1997) \\
\hline & Shipping errors & $\begin{array}{l}\text { Kim et al. (2010), fast moving global } \\
\text { markets }\end{array}$ \\
\hline & Shorter lead times & $\begin{array}{l}\text { Min et al. (2005); Reniers et al. (2010), } \\
\text { chemical industry, shipper perspective }\end{array}$ \\
\hline & Shorter order cycles & Fawcett et al. (2008b) \\
\hline & Shorter order fulfilment lead times & Fawcett et al. (2008a) \\
\hline & Superior quality & Fawcett et al. (2008b) \\
\hline & Streamlining supply chain process & Min et al. (2005) \\
\hline & $\begin{array}{l}\text { Surcharge reduction for customers for } \\
\text { negotiating other time slots with retailer }\end{array}$ & *, FMCG industry, LSP perspective \\
\hline & Time reduction & $\begin{array}{l}\text { *, FMCG industry, LSP and retailer } \\
\text { perspective }\end{array}$ \\
\hline \multirow{11}{*}{$\begin{array}{l}\text { Enhanced enablers: Factors } \\
\text { which indicate an improvement } \\
\text { in the enablers through } \\
\text { collaboration }\end{array}$} & Access to missing knowledge & $\begin{array}{l}\text { Visser (2010), logistics collaboration, } \\
\text { shipper perspective }\end{array}$ \\
\hline & Enhanced conflict resolution & Maloni and Benton (1997) \\
\hline & $\begin{array}{l}\text { Enhancing relationship towards } \\
\text { customer }\end{array}$ & $\begin{array}{l}* \text {, FMCG industry, manufacturer } \\
\text { perspective }\end{array}$ \\
\hline & Improved expertise & $\begin{array}{l}\text { Visser (2010), logistics outsourcing, } \\
\text { shipper perspective }\end{array}$ \\
\hline & $\begin{array}{l}\text { Learning and internationalization of } \\
\text { tacit, collective and embedded } \\
\text { knowledge and skills }\end{array}$ & $\begin{array}{l}\text { Cruijssen et al. (2007), transport and } \\
\text { logistics industry, LSP perspective }\end{array}$ \\
\hline & Mutuality beneficial and synergistic & Min et al. (2005) \\
\hline & Mutual learning & $\begin{array}{l}\text { Beach et al. (2005), construction } \\
\text { industry, manufacturer perspective }\end{array}$ \\
\hline & Mutual rewards and benefits & $\begin{array}{l}\text { Beach et al. (2005), construction } \\
\text { industry, manufacturer perspective }\end{array}$ \\
\hline & Skill enhancement & $\begin{array}{l}\text { Ahmad and Ullah (2013); Cruijssen et al. } \\
\text { (2007), transport and logistics industry, } \\
\text { LSP perspective }\end{array}$ \\
\hline & Strong partnership & $\begin{array}{l}*, \text { FMCG industry, manufacturer } \\
\text { perspective }\end{array}$ \\
\hline & Superior channel relationship & Fawcett et al. (2008b) \\
\hline \multirow{8}{*}{$\begin{array}{l}\text { Flexibility improvements: } \\
\text { Factors which indicate } \\
\text { improvements in every kind of } \\
\text { flexibility through collaboration }\end{array}$} & Ability to handle unexpected events & Fawcett et al. (2008a) \\
\hline & Flexible customer response & Fawcett et al. (2008b) \\
\hline & Information system flexibility & $\begin{array}{l}\text { Kim et al. (2010), fast moving global } \\
\text { markets }\end{array}$ \\
\hline & Logistics flexibility & $\begin{array}{l}\text { Kim et al. (2010), fast moving global } \\
\text { markets }\end{array}$ \\
\hline & Market flexibility & $\begin{array}{l}\text { Horvath (2001); Kim et al. (2010), fast } \\
\text { moving global markets }\end{array}$ \\
\hline & Operational flexibility & $\begin{array}{l}\text { Visser (2010), logistics outsourcing and } \\
\text { chemical industry, shipper perspective }\end{array}$ \\
\hline & Organizational flexibility & $\begin{array}{l}\text { Kim et al. (2010), fast moving global } \\
\text { markets }\end{array}$ \\
\hline & Provide more flexible systems & $\begin{array}{l}\text { Visser (2010), logistics outsourcing, } \\
\text { shipper perspective }\end{array}$ \\
\hline
\end{tabular}




\begin{tabular}{|c|c|c|}
\hline General Factor & Factor & Paper, Industry and Perspective \\
\hline \multirow{2}{*}{$\begin{array}{l}\text { Flexibility improvements: } \\
\text { Factors which indicate } \\
\text { improvements in every kind of } \\
\text { flexibility through collaboration }\end{array}$} & Strategic flexibility & $\begin{array}{l}\text { Visser (2010), logistics outsourcing, } \\
\text { shipper perspective }\end{array}$ \\
\hline & Supply flexibility & $\begin{array}{l}\text { Kim et al. (2010), fast moving global } \\
\text { markets }\end{array}$ \\
\hline \multirow{4}{*}{$\begin{array}{l}\text { Image improvements: Factors } \\
\text { which indicate improvements } \\
\text { in the reputation of a party }\end{array}$} & Enhancing public image & $\begin{array}{l}\text { Cruijssen et al. (2007), transport and } \\
\text { logistics industry, LSP perspective }\end{array}$ \\
\hline & Image improvements & *, FMCG, manufacturer perspective \\
\hline & Potential for receiving publicity & Walker et al. (2008) \\
\hline & Professionalism & *, FMCG, manufacturer perspective \\
\hline \multirow{7}{*}{$\begin{array}{l}\text { Market position } \\
\text { improvements: Factors which } \\
\text { indicate improvements in the } \\
\text { ranking of a brand, product or } \\
\text { party in terms of its sales } \\
\text { volume relative to the sales } \\
\text { volume of its competitors in } \\
\text { the same market or industry }\end{array}$} & Access into new markets & $\begin{array}{l}\text { Cruijssen et al. (2007), transport and } \\
\text { logistics industry, LSP perspective; } \\
\text { Fawcett et al. (2008a); Visser (2010), } \\
\text { logistics collaboration, shipper } \\
\text { perspective }\end{array}$ \\
\hline & Increase in market share & $\begin{array}{l}\text { Ahmad and Ullah (2013), Min et al. } \\
\text { (2005), Simatupang and Sridharan (2002) }\end{array}$ \\
\hline & New product development & $\begin{array}{l}\text { Cruijssen et al. (2007), transport and } \\
\text { logistics industry, LSP perspective; Min } \\
\text { et al. (2005) }\end{array}$ \\
\hline & Product quality improvements & $\begin{array}{l}\text { Ahmad and Ullah (2013); Fawcett et al. } \\
\text { (2008a) }\end{array}$ \\
\hline & Protecting market share & $\begin{array}{l}\text { Cruijssen et al. (2007), transport and } \\
\text { logistics industry, LSP perspective }\end{array}$ \\
\hline & Serving larger customers & $\begin{array}{l}\text { Cruijssen et al. (2007), transport and } \\
\text { logistics industry, LSP perspective }\end{array}$ \\
\hline & Unique products and services & Fawcett et al. (2008b) \\
\hline \multirow{2}{*}{$\begin{array}{l}\text { Marketing advantages: Factors } \\
\text { which indicate improvements } \\
\text { in marketing activities }\end{array}$} & Marketing advantages & Lambert et al. (1996) \\
\hline & $\begin{array}{l}\text { Forecast accuracy throughout the entire } \\
\text { supply chain }\end{array}$ & Fawcett et al. (2008b) \\
\hline \multirow{7}{*}{$\begin{array}{l}\text { Risk reduction: Factors which } \\
\text { indicate a reduction of every } \\
\text { kind of risk }\end{array}$} & Decreased risk from externalities & Maloni and Benton (1997) \\
\hline & $\begin{array}{l}\text { Decreased risk in product development } \\
\text { failure }\end{array}$ & Ahmad and Ullah (2013) \\
\hline & Environmental risk minimization & Walker et al. (2008), retailer perspective \\
\hline & Less risk of opportunism & Maloni and Benton (1997) \\
\hline & Reduced risk for customer criticism & Walker et al. (2008) \\
\hline & Reduced risk of information failure & Min and Zhou (2002) \\
\hline & Risk reduction & $\begin{array}{l}\text { Visser (2010), logistics collaboration, } \\
\text { shipper perspective }\end{array}$ \\
\hline \multirow{5}{*}{$\begin{array}{l}\text { Sustainability improvements: } \\
\text { Factors which indicate } \\
\text { improvements in e. g. the } \\
\text { environmental sustainability }\end{array}$} & $\mathrm{CO}_{2}$-reduction & $\begin{array}{l}* \text {, FMCG industry, manufacturer, LSP and } \\
\text { retailer perspective }\end{array}$ \\
\hline & $\begin{array}{l}\text { Environmental performance } \\
\text { improvements }\end{array}$ & Walker et al. (2008) \\
\hline & Minimizing waste and pollution & Walker et al. (2008) \\
\hline & Regeneration of local areas & Walker et al. (2008) \\
\hline & Sustainability & $\begin{array}{l}* \text {, FMCG industry, manufacturer } \\
\text { perspective }\end{array}$ \\
\hline \multirow{5}{*}{$\begin{array}{l}\text { Technology improvements: } \\
\text { Factors which indicate } \\
\text { improvements in every kind of } \\
\text { technology }\end{array}$} & Access superior technology & $\begin{array}{l}\text { Cruijssen et al. (2007), transport and } \\
\text { logistics industry, LSP perspective }\end{array}$ \\
\hline & Developing technical standards & $\begin{array}{l}\text { Cruijssen et al. (2007), transport and } \\
\text { logistics industry, LSP perspective }\end{array}$ \\
\hline & Offers new possibilities/ technologies & *, FMCG industry, retailer perspective \\
\hline & Technology transfers & Min and Zhou (2002) \\
\hline & $\begin{array}{l}\text { Using technology also for other } \\
\text { customers }\end{array}$ & *, FMCG industry, LSP perspective \\
\hline
\end{tabular}




\section{Allocation Forces}

Table 6: Allocation forces

\begin{tabular}{|c|c|c|}
\hline General Factor & Factor & Paper, Industry and Perspective \\
\hline \multirow{5}{*}{$\begin{array}{l}\text { Customer issues: Factors which } \\
\text { indicate that the force is based } \\
\text { on markets and customers' } \\
\text { demands }\end{array}$} & $\begin{array}{l}\text { Customer demand becomes } \\
\text { less and less predictable }\end{array}$ & de Leeuw and Fransoo (2009); Richey et al. (2009) \\
\hline & $\begin{array}{l}\text { Customer demand products } \\
\text { consistently delivered faster } \\
\text { and more reliable }\end{array}$ & Richey et al. (2009) \\
\hline & Fast changing market demands & Richey et al. (2009) \\
\hline & Greater supply uncertainty & de Leeuw and Fransoo (2009) \\
\hline & More demanding customers & Fawcett et al. (2008a); Fawcett et al. (2008b) \\
\hline \multirow{15}{*}{$\begin{array}{l}\text { Forced by other parties: } \\
\text { Factors which indicate that a } \\
\text { party is forced by another party } \\
\text { of the supply chain and/or the } \\
\text { surrounding of a party }\end{array}$} & $\begin{array}{l}\text { Champions values for green } \\
\text { SCM }\end{array}$ & Walker et al. (2008) \\
\hline & Demanded by customers & Walker et al. (2008), retailer perspective \\
\hline & Demanded by manufacturer & *, FMCG industry, LSP perspective \\
\hline & Forced by retailer & $\begin{array}{l}* \text {, FMCG industry, manufacturer and LSP } \\
\text { perspective }\end{array}$ \\
\hline & $\begin{array}{l}\text { Legislative and regulatory } \\
\text { compliance }\end{array}$ & Walker et al. (2008) \\
\hline & Marketing pressure & Walker et al. (2008) \\
\hline & $\begin{array}{l}\text { Organizational values for green } \\
\text { SCM }\end{array}$ & Walker et al. (2008) \\
\hline & Owner Values for green SCM & Walker et al. (2008) \\
\hline & Power & Richey et al. (2009) \\
\hline & $\begin{array}{l}\text { Pressure by environmental } \\
\text { advocacy groups }\end{array}$ & Walker et al. (2008) \\
\hline & Pressure from investors & Walker et al. (2008) \\
\hline & Proactive action pre-regulation & Walker et al. (2008) \\
\hline & Public pressure & Walker et al. (2008) \\
\hline & Regulatory compliance & Walker et al. (2008), retailer perspective \\
\hline & $\begin{array}{l}\text { Stakeholder can encourage } \\
\text { environmental strategy }\end{array}$ & Walker et al. (2008) \\
\hline \multirow[b]{2}{*}{$\begin{array}{l}\text { Globalization: Factors which } \\
\text { indicate that the party is forced } \\
\text { due to worldwide movements } \\
\text { towards economic, financial, } \\
\text { trade and communication } \\
\text { integration }\end{array}$} & Economic globalization & Fawcett et al. (2008a); Fawcett et al. (2008b) \\
\hline & $\begin{array}{l}\text { Shift to supply chain-based } \\
\text { business models }\end{array}$ & Fawcett et al. (2008b) \\
\hline $\begin{array}{l}\text { Greater competitive intensity: } \\
\text { Factors which indicate that the } \\
\text { force is based on } \\
\text { competitiveness issues }\end{array}$ & Greater competitive intensity & Fawcett et al. (2008a); Fawcett et al. (2008b) \\
\hline \multirow{4}{*}{$\begin{array}{l}\text { Information issues: Factors } \\
\text { which indicate that the force is } \\
\text { based on information issues }\end{array}$} & Need for better information & Fawcett et al. (2008a) \\
\hline & Information revolution & Fawcett et al. (2008b) \\
\hline & Increased financial pressure & Fawcett et al. (2008b) \\
\hline & Pressure for lower prices & Walker et al. (2008) \\
\hline \multirow{2}{*}{$\begin{array}{l}\text { Shifting issues: Factors which } \\
\text { indicate that the force is based } \\
\text { on changes in persons, } \\
\text { configurations or focusses }\end{array}$} & Shifting channel power & Fawcett et al. (2008a); Fawcett et al. (2008b) \\
\hline & Shifting competitive focus & Fawcett et al. (2008a) \\
\hline $\begin{array}{l}\text { Technology issues: Factors } \\
\text { which indicate that the force is } \\
\text { based on technology issues }\end{array}$ & New information technology & Fawcett et al. (2008a) \\
\hline
\end{tabular}


Table 6 (continued)

General Factor

Tighter relationships: Factors

which indicate that the force is

based on changes in

relationships

Time issues: Factors which

indicate that the force is based

on time issues
Paper, Industry and Perspective

Fawcett et al. (2008a); Fawcett et al. (2008b)

Fawcett et al. (2008a)

Fawcett et al. (2008a); Richey et al. (2009)

Fawcett et al. (2008b)
Compressed product cycles

Compressed technology cycles
Merge and acquisition activities

Tighter alliance relationships 


\section{Allocation Enablers/Barriers}

Table 7: Allocation enablers/barriers

\begin{tabular}{|c|c|c|c|}
\hline General Factor & Enablers/Barriers & Factor & $\begin{array}{l}\text { Paper, Industry and } \\
\text { Perspective }\end{array}$ \\
\hline \multirow{17}{*}{$\begin{array}{l}\text { Presence of absence } \\
\text { of barriers: Factors } \\
\text { which indicate the } \\
\text { presence or absence } \\
\text { of legal, industrial or } \\
\text { organizational specific } \\
\text { barriers }\end{array}$} & \multirow[t]{6}{*}{$\begin{array}{l}\text { Presence of absence } \\
\text { of barriers }\end{array}$} & Compliance & $\begin{array}{l}*, \text { FMCG industry, } \\
\text { manufacturer perspective }\end{array}$ \\
\hline & & No legal barriers & $\begin{array}{l}* \text {, FMCG industry, LSP } \\
\text { perspective }\end{array}$ \\
\hline & & $\begin{array}{l}\text { Overcoming legal and regulatory } \\
\text { barriers }\end{array}$ & $\begin{array}{l}\text { Cruijssen et al. (2007), } \\
\text { transport and logistics } \\
\text { industry, LSP perspective }\end{array}$ \\
\hline & & $\begin{array}{l}\text { Overcoming procedural and structural } \\
\text { barriers }\end{array}$ & Maloni and Benton (1997) \\
\hline & & $\begin{array}{l}\text { Overcoming social and attitudinal } \\
\text { barriers }\end{array}$ & Maloni and Benton (1997) \\
\hline & & $\begin{array}{l}\text { PR exercise as greenwash (lack of } \\
\text { legitimacy) }\end{array}$ & Walker et al. (2008) \\
\hline & \multirow[t]{11}{*}{$\begin{array}{l}\text { Lack of absence of } \\
\text { barriers }\end{array}$} & $\begin{array}{l}\text { Clinical preferences - not too much } \\
\text { focus on environmental improvements }\end{array}$ & $\begin{array}{l}\text { Walker et al. (2008), } \\
\text { retailer perspective }\end{array}$ \\
\hline & & Horizontal collaboration difficult & $\begin{array}{l}*, \text { FMCG industry, } \\
\text { manufacturer perspective }\end{array}$ \\
\hline & & Industry specific barriers & $\begin{array}{l}\text { Walker et al. (2008), } \\
\text { retailer perspective }\end{array}$ \\
\hline & & Legal barriers & $\begin{array}{l}*, \text { FMCG industry, LSP and } \\
\text { manufacturer perspective }\end{array}$ \\
\hline & & Local nature of the project & $\begin{array}{l}\text { Walker et al. (2008), } \\
\text { retailer perspective }\end{array}$ \\
\hline & & Organizational boundaries & $\begin{array}{l}\text { Akintoye et al. (2000), } \\
\text { construction industry, } \\
\text { manufacturer perspective; } \\
\text { Fawcett et al. (2008a) }\end{array}$ \\
\hline & & Organization culture barriers & $\begin{array}{l}\text { Walker et al. (2008), } \\
\text { retailer perspective }\end{array}$ \\
\hline & & Other projects have higher priorities & $\begin{array}{l}*, \text { FMCG industry, retailer } \\
\text { perspective }\end{array}$ \\
\hline & & $\begin{array}{l}\text { Procurement legislation - competing } \\
\text { procurement priorities (patient safety } \\
\text { before environmental improvement) }\end{array}$ & $\begin{array}{l}\text { Walker et al. (2008), } \\
\text { retailer perspective }\end{array}$ \\
\hline & & Scale of supply chain & $\begin{array}{l}\text { Walker et al. (2008), } \\
\text { retailer perspective }\end{array}$ \\
\hline & & $\begin{array}{l}\text { When parties are in a horizontal } \\
\text { collaboration it can be hard to } \\
\text { distinguish oneself towards the other } \\
\text { parties }\end{array}$ & $\begin{array}{l}\text { Cruijssen et al. (2007), } \\
\text { transport and logistics } \\
\text { industry, LSP perspective }\end{array}$ \\
\hline \multirow{4}{*}{$\begin{array}{l}\text { Presence of absence } \\
\text { of costs: Factors } \\
\text { which indicate a } \\
\text { change or not in the } \\
\text { costs }\end{array}$} & \multirow[t]{4}{*}{$\begin{array}{l}\text { Lack of absence of } \\
\text { costs }\end{array}$} & Financial investments & $\begin{array}{l}\text { Lambert et al. (1996); } \\
\text { Maloni and Benton (1997) }\end{array}$ \\
\hline & & $\begin{array}{l}\text { High coordination costs due to } \\
\text { differences in operating procedures }\end{array}$ & $\begin{array}{l}\text { Cruijssen et al. (2007), } \\
\text { transport and logistics } \\
\text { industry, LSP perspective }\end{array}$ \\
\hline & & High investments in technology & $\begin{array}{l}\text { Cruijssen et al. (2007), } \\
\text { transport and logistics } \\
\text { industry, LSP perspective; *, } \\
\text { FMCG industry, LSP and } \\
\text { retailer perspective }\end{array}$ \\
\hline & & Increased costs & $\begin{array}{l}\text { Walker et al. (2008), } \\
\text { retailer perspective; }{ }^{*}, \\
\text { FMCG industry, } \\
\text { manufacturer perspective }\end{array}$ \\
\hline
\end{tabular}


Table 7 (continued)

\begin{tabular}{|c|c|c|c|}
\hline General Factor & Enablers/Barriers & Factor & $\begin{array}{l}\text { Paper, Industry and } \\
\text { Perspective }\end{array}$ \\
\hline \multirow{6}{*}{$\begin{array}{l}\text { Presence of absence } \\
\text { of costs: Factors } \\
\text { which indicate a } \\
\text { change or not in the } \\
\text { costs }\end{array}$} & \multirow[t]{6}{*}{$\begin{array}{l}\text { Lack of absence of } \\
\text { costs }\end{array}$} & $\begin{array}{l}\text { Process poorly appraised in terms of } \\
\text { costs }\end{array}$ & Fawcett et al. (2008a) \\
\hline & & Upfront investments & $\begin{array}{l}\text { Cruijssen et al. (2007), } \\
\text { transport and logistics } \\
\text { industry, LSP perspective; } \\
\text { Min et al. (2005); }{ }^{*}, \text { FMCG } \\
\text { industry, LSP, manufacturer } \\
\text { and retailer perspective }\end{array}$ \\
\hline & & Sunk costs & $\begin{array}{l}\text { Visser (2010), logistics } \\
\text { outsourcing, shipper } \\
\text { perspective }\end{array}$ \\
\hline & & Switching costs & $\begin{array}{l}\text { Visser (2010), logistics } \\
\text { collaboration and } \\
\text { outsourcing, shipper } \\
\text { perspective }\end{array}$ \\
\hline & & $\begin{array}{l}\text { Time windows lead to higher costs due } \\
\text { to inflexibility }\end{array}$ & $\begin{array}{l}\text { *, FMCG industry, LSP } \\
\text { perspective }\end{array}$ \\
\hline & & Transaction costs & $\begin{array}{l}\text { Visser (2010), logistics } \\
\text { collaboration and } \\
\text { outsourcing, shipper } \\
\text { perspective }\end{array}$ \\
\hline $\begin{array}{l}\text { Presence of } \\
\text { accountability: } \\
\text { Factors which } \\
\text { indicates the } \\
\text { obligation or not of a } \\
\text { person or a party for } \\
\text { something }\end{array}$ & $\begin{array}{l}\text { Presence of } \\
\text { accountability }\end{array}$ & Clarity of accountability & Riggin et al. (1992) \\
\hline \multirow{2}{*}{$\begin{array}{l}\text { Presence of } \\
\text { appropriate kind of } \\
\text { relationship: Factors } \\
\text { which indicate the } \\
\text { choice of the right } \\
\text { type of relationship }\end{array}$} & \multirow[t]{2}{*}{$\begin{array}{l}\text { Presence of } \\
\text { appropriate kind of } \\
\text { relationship }\end{array}$} & $\begin{array}{l}\text { Define an appropriate type of } \\
\text { relationship to establish with specific } \\
\text { supply chain members }\end{array}$ & Fawcett et al. (2008b) \\
\hline & & Scope & Lambert et al. (1996) \\
\hline \multirow{5}{*}{$\begin{array}{l}\text { Presence of } \\
\text { capabilities: Factors } \\
\text { which indicate the } \\
\text { availability or the lack } \\
\text { of an ability of an } \\
\text { entity }\end{array}$} & \multirow{5}{*}{$\begin{array}{l}\text { Presence of } \\
\text { capabilities }\end{array}$} & Ability to meet expectation & Cao and Zhang (2011) \\
\hline & & High-level service capabilities & Horvath (2001) \\
\hline & & $\begin{array}{l}\text { Large, flexible, multimedia data } \\
\text { storage capabilities }\end{array}$ & Horvath (2001) \\
\hline & & Partner capabilities & $\begin{array}{l}\text { Kim et al. (2010), fast } \\
\text { moving global markets; } \\
\text { Maloni and Benton (1997); } \\
\text { Visser (2010), chemical } \\
\text { industry, shipper } \\
\text { perspective }\end{array}$ \\
\hline & & Sophisticated security capabilities & Horvath (2001) \\
\hline
\end{tabular}


Table 7 (continued)

\begin{tabular}{|c|c|c|c|}
\hline General Factor & Enablers/Barriers & Factor & $\begin{array}{l}\text { Paper, Industry and } \\
\text { Perspective }\end{array}$ \\
\hline \multirow[t]{9}{*}{$\begin{array}{l}\text { Presence of } \\
\text { commitment and } \\
\text { support: Factors } \\
\text { which indicate the } \\
\text { commitment and/ or } \\
\text { the support of party } \\
\text { members or people of } \\
\text { the surrounding }\end{array}$} & \multirow[t]{6}{*}{$\begin{array}{l}\text { Presence of } \\
\text { commitment and } \\
\text { support }\end{array}$} & Commitment & $\begin{array}{l}\text { Ahmad and Ullah (2013), } \\
\text { manufacturer perspective; } \\
\text { Barrat (2004); Cruijssen et } \\
\text { al. (2007), transport and } \\
\text { logistics industry, LSP } \\
\text { perspective; Fawcett et al. } \\
\text { (2008b); Heikkilä (2002), } \\
\text { telecommunication } \\
\text { industry; Kim et al. (2010), } \\
\text { fast moving global market; } \\
\text { Lambert et al. (1996); } \\
\text { Maheshwari et al. (2006); } \\
\text { Mohr and Spekman (1994), } \\
\text { computer industry, dealer } \\
\text { perspective; Perry and } \\
\text { Sohal (2001), textiles, } \\
\text { clothes and foot wear } \\
\text { industry; Ryu et al. (2009); } \\
\text { Visser (2010), chemical } \\
\text { industry and logistics } \\
\text { collaboration, shipper } \\
\text { perspective; *, FMCG } \\
\text { industry, LSP, manufacturer } \\
\text { and retailer perspective }\end{array}$ \\
\hline & & Internal stakeholder support & $\begin{array}{l}\text { Reniers et al. (2010), } \\
\text { chemical industry, shipper } \\
\text { perspective }\end{array}$ \\
\hline & & Intra-organizational support & Barrat (2004) \\
\hline & & Top management commitment & $\begin{array}{l}\text { Anbanandam et al. (2011), } \\
\text { apparel industry, retailer } \\
\text { and manufacturer } \\
\text { perspective; Fawcett et al. } \\
\text { (2008b) }\end{array}$ \\
\hline & & Top management support & $\begin{array}{l}\text { Akintoye et al. (2000), } \\
\text { construction industry, } \\
\text { manufacturer perspective; } \\
\text { Brinkerhoff (2002); Ellram } \\
\text { (1995), buyer perspective; } \\
\text { Fawcett et al. (2008b); } \\
\text { Maloni and Benton (1997); } \\
\text { Niderkofler (1991) }\end{array}$ \\
\hline & & Mutual commitment & $\begin{array}{l}\text { Ellram (1995), buyer } \\
\text { perspective }\end{array}$ \\
\hline & \multirow[t]{3}{*}{$\begin{array}{l}\text { Lack of commitment } \\
\text { and support }\end{array}$} & $\begin{array}{l}\text { Homogeneity: internal support and } \\
\text { commitment of all stakeholders }\end{array}$ & $\begin{array}{l}\text { Visser (2010), logistics } \\
\text { collaboration, shipper } \\
\text { perspective }\end{array}$ \\
\hline & & Inhibit innovativeness & Walker et al. (2008) \\
\hline & & $\begin{array}{l}\text { Lack of support from within the larger } \\
\text { firm }\end{array}$ & Niderkofler (1991) \\
\hline
\end{tabular}


Table 7 (continued)

\begin{tabular}{|c|c|c|c|}
\hline General Factor & Enablers/Barriers & Factor & $\begin{array}{l}\text { Paper, Industry and } \\
\text { Perspective }\end{array}$ \\
\hline \multirow[t]{3}{*}{$\begin{array}{l}\text { Presence of } \\
\text { commitment and } \\
\text { support: Factors } \\
\text { which indicate the } \\
\text { commitment and/ or } \\
\text { the support of party } \\
\text { members or people of } \\
\text { the surrounding }\end{array}$} & \multirow[t]{3}{*}{$\begin{array}{l}\text { Lack of commitment } \\
\text { and support }\end{array}$} & $\begin{array}{l}\text { Lack of (top) management } \\
\text { commitment }\end{array}$ & $\begin{array}{l}\text { Akintoye et al. (2000), } \\
\text { construction industry, } \\
\text { manufacturer perspective; } \\
\text { Visser (2010), logistics } \\
\text { collaboration and } \\
\text { outsourcing, shipper } \\
\text { perspective; Walker et al. } \\
\text { (2008) }\end{array}$ \\
\hline & & Lack of top management support & $\begin{array}{l}\text { Fawcett et al. (2008b); } \\
\text { Lambert et al. (1999), } \\
\text { manufacturer and third } \\
\text { party provider perspective }\end{array}$ \\
\hline & & Low commitment of partners & $\begin{array}{l}\text { Akintoye et al. (2000), } \\
\text { construction industry, } \\
\text { manufacturer perspective }\end{array}$ \\
\hline \multirow{8}{*}{$\begin{array}{l}\text { Presence of } \\
\text { communication: } \\
\text { Factors which indicate } \\
\text { formal and informal } \\
\text { information sharing } \\
\text { with the partners in a } \\
\text { timely and quality } \\
\text { manner or not; it also } \\
\text { includes the way of } \\
\text { how information are } \\
\text { shared or not }\end{array}$} & \multirow[t]{8}{*}{$\begin{array}{l}\text { Presence of } \\
\text { communication }\end{array}$} & Access to environmental information & $\begin{array}{l}\text { Walker et al. (2008), } \\
\text { retailer perspective }\end{array}$ \\
\hline & & Communication & $\begin{array}{l}\text { Beach et al. (2005), } \\
\text { construction industry, } \\
\text { manufacturer perspective; } \\
\text { Cao and Zhang (2011); } \\
\text { Ellram (1995), buyer } \\
\text { perspective; Fawcett et al. } \\
\text { (2008a); Kim et al. (2010), } \\
\text { fast moving global markets; } \\
\text { Lambert et al. (1996); } \\
\text { Maloni and Benton (1997); } \\
\text { Perry and Sohal (2001), } \\
\text { textiles, clothing and foot } \\
\text { wear industry; Ryu et al. } \\
\text { (2009) }\end{array}$ \\
\hline & & $\begin{array}{l}\text { Communication behaviour - } \\
\text { participation }\end{array}$ & $\begin{array}{l}\text { Heikkilä (2002), } \\
\text { telecommunication } \\
\text { industry; Mohr and } \\
\text { Spekman (1994), computer } \\
\text { industry, dealer perspective }\end{array}$ \\
\hline & & Communication quality & $\begin{array}{l}\text { Ahmad and Ullah (2013), } \\
\text { manufacturer perspective; } \\
\text { Heikkilä (2002), } \\
\text { telecommunication } \\
\text { industry; Mohr and } \\
\text { Spekman (1994), computer } \\
\text { industry, dealer perspective }\end{array}$ \\
\hline & & $\begin{array}{l}\text { Electronic data interchange (EDI) } \\
\text { linkage }\end{array}$ & Fawcett et al. (2008a) \\
\hline & & ERP/SCM software & Fawcett et al. (2008a) \\
\hline & & Free flow of information & $\begin{array}{l}\text { Akintoye et al. (2000), } \\
\text { construction industry, } \\
\text { manufacturer perspective; } \\
\text { Min et al. (2005) }\end{array}$ \\
\hline & & Heightened communication & Min et al. (2005) \\
\hline
\end{tabular}


Table 7 (continued)

\begin{tabular}{|c|c|c|c|}
\hline General Factor & Enablers/Barriers & Factor & $\begin{array}{l}\text { Paper, Industry and } \\
\text { Perspective }\end{array}$ \\
\hline \multirow[t]{14}{*}{$\begin{array}{l}\text { Presence of } \\
\text { communication: } \\
\text { Factors which indicate } \\
\text { formal and informal } \\
\text { information sharing } \\
\text { with the partners in a } \\
\text { timely and quality } \\
\text { manner or not; it also } \\
\text { includes the way of } \\
\text { how information are } \\
\text { shared or not }\end{array}$} & \multirow[t]{11}{*}{$\begin{array}{l}\text { Presence of } \\
\text { communication }\end{array}$} & Information sharing & $\begin{array}{l}\text { Ahmad and Ullah (2013); } \\
\text { manufacturer perspective; } \\
\text { Anbanandam et al. (2011), } \\
\text { apparel retail industry, } \\
\text { manufacturer and retailer } \\
\text { perspective; Barrat (2004); } \\
\text { Cao and Zhang (2011); } \\
\text { Cruijssen et al. (2007), } \\
\text { transport and logistics } \\
\text { industry, LSP perspective; } \\
\text { Ellram (1995), buyer } \\
\text { perspective; Fawcett et al. } \\
\text { (2008a); Fawcett et al. } \\
\text { (2008b); Heikkilä (2002), } \\
\text { telecommunication } \\
\text { industry; Mohr and } \\
\text { Spekman (1994), computer } \\
\text { industry, dealer } \\
\text { perspective; Simatupang } \\
\text { and Sridharan (2002); }{ }^{*}, \\
\text { FMCG industry, LSP, } \\
\text { manufacturer and retailer } \\
\text { perspective }\end{array}$ \\
\hline & & Information technology & $\begin{array}{l}\text { Cruijssen et al. (2007), } \\
\text { transport and logistics } \\
\text { industry, LSP perspective; } \\
\text { Fawcett et al. (2008b); }{ }^{*}, \\
\text { FMCG industry, LSP, } \\
\text { manufacturer and retailer } \\
\text { perspective }\end{array}$ \\
\hline & & Integrated information system & $\begin{array}{l}\text { Akintoye et al. (2000), } \\
\text { construction industry, } \\
\text { manufacturer perspective }\end{array}$ \\
\hline & & Intense and open communication & Niderkofler (1991) \\
\hline & & Intelligence gathering and analysis & Horvath (2001) \\
\hline & & Real time communication & Min and Zhou (2002) \\
\hline & & Revenue-tracking system & Fawcett et al. (2008b) \\
\hline & & Social exchange & Maloni and Benton (1997) \\
\hline & & $\begin{array}{l}\text { Supplier is informed of and involved in } \\
\text { changes and new product design }\end{array}$ & $\begin{array}{l}\text { Ellram (1995), buyer } \\
\text { perspective }\end{array}$ \\
\hline & & SCC exchange & Horvath (2001) \\
\hline & & Technology & $\begin{array}{l}\text { Ahmad and Ullah (2013), } \\
\text { manufacturer perspective; } \\
\text { Barrat (2004); Boddy et al. } \\
(2000)\end{array}$ \\
\hline & \multirow[t]{3}{*}{$\begin{array}{l}\text { Lack of } \\
\text { communication }\end{array}$} & $\begin{array}{l}\text { Availability, accessibility and validity of } \\
\text { data }\end{array}$ & Riggin et al. (1992) \\
\hline & & $\begin{array}{l}\text { Communication within triangular } \\
\text { relationships is lacking, because the } \\
\text { communication between LSP and } \\
\text { retailer is not existing }\end{array}$ & $\begin{array}{l}*, \text { FMCG industry, retailer } \\
\text { perspective }\end{array}$ \\
\hline & & $\begin{array}{l}\text { Connecting different IDT systems is } \\
\text { very difficult and complex }\end{array}$ & $\begin{array}{l}*, \text { FMCG industry, LSP and } \\
\text { manufacturer perspective }\end{array}$ \\
\hline
\end{tabular}


Table 7 (continued)

\begin{tabular}{|c|c|c|c|}
\hline General Factor & Enablers/Barriers & Factor & $\begin{array}{l}\text { Paper, Industry and } \\
\text { Perspective }\end{array}$ \\
\hline \multirow{7}{*}{$\begin{array}{l}\text { Presence of } \\
\text { communication: } \\
\text { Factors which indicate } \\
\text { formal and informal } \\
\text { information sharing } \\
\text { with the partners in a } \\
\text { timely and quality } \\
\text { manner or not; it also } \\
\text { includes the way of } \\
\text { how information are } \\
\text { shared or not }\end{array}$} & \multirow[t]{7}{*}{$\begin{array}{l}\text { Lack of } \\
\text { communication }\end{array}$} & $\begin{array}{l}\text { Insufficient communication at internal } \\
\text { retailer side }\end{array}$ & $\begin{array}{l}* \text {, FMCG industry, LSP } \\
\text { perspective }\end{array}$ \\
\hline & & $\begin{array}{l}\text { Lack of appropriate information } \\
\text { technology }\end{array}$ & $\begin{array}{l}\text { Akintoye et al. (2000), } \\
\text { construction industry, } \\
\text { manufacturer perspective; } \\
\text { Fawcett et al. (2008a) }\end{array}$ \\
\hline & & Lack of information sharing & $\begin{array}{l}\text { Fawcett et al. (2008a); } \\
\text { Fawcett et al. (2008b); } \\
\text { Lambert et al. (1999), } \\
\text { manufacturer and third } \\
\text { party logistics perspective; } \\
\text { Walker et al. (2008), } \\
\text { retailer perspective }\end{array}$ \\
\hline & & $\begin{array}{l}\text { No implementation issues addressed } \\
\text { during negotiation process }\end{array}$ & Niderkofler (1991) \\
\hline & & Only old WMS available & $\begin{array}{l}*, \text { FMCG industry, retailer } \\
\text { perspective }\end{array}$ \\
\hline & & $\begin{array}{l}\text { Sharing confidential information } \\
\text { within vertical SCC is very difficult }\end{array}$ & $\begin{array}{l}\text { *, FMCG industry, retailer } \\
\text { perspective }\end{array}$ \\
\hline & & Very complex ICT system & $\begin{array}{l}\text { *, FMCG industry, LSP } \\
\text { perspective }\end{array}$ \\
\hline \multirow{10}{*}{$\begin{array}{l}\text { Presence of } \\
\text { compatibility: Factors } \\
\text { which indicate } \\
\text { complementarities or } \\
\text { not between the } \\
\text { parties in terms of e.g. } \\
\text { goals, culture, } \\
\text { objective and } \\
\text { operating philosophy }\end{array}$} & \multirow{10}{*}{$\begin{array}{l}\text { Presence of } \\
\text { compatibility }\end{array}$} & Business process compatibility & Boddy et al. (2000) \\
\hline & & Common/ clear expectation & $\begin{array}{l}\text { Cruijssen et al. (2007), } \\
\text { transport and logistics } \\
\text { industry, LSP perspective }\end{array}$ \\
\hline & & Common/ clear goals & $\begin{array}{l}\text { Brinkerhoff (2002); Cao and } \\
\text { Zhang (2011); Fawcett et al. } \\
\text { (2008a); * , FMCG industry, } \\
\text { LSP perspective; Maloni } \\
\text { and Benton (1997) }\end{array}$ \\
\hline & & Common interests & $\begin{array}{l}\text { Akintoye et al. (2000), } \\
\text { construction industry, } \\
\text { manufacturer perspective; } \\
\text { Cruijssen et al. (2007), } \\
\text { transport and logistics } \\
\text { industry, LSP perspective }\end{array}$ \\
\hline & & Common operating procedures & Fawcett et al. (2008a) \\
\hline & & Common vision & $\begin{array}{l}\text { Beach et al. (2005), } \\
\text { construction industry, } \\
\text { manufacturer perspective; } \\
\text { Fawcett et al. (2008b) }\end{array}$ \\
\hline & & Compatibility in the structure & Boddy et al. (2000) \\
\hline & & Complementary goods and services & $\begin{array}{l}\text { Cruijssen et al. (2007), } \\
\text { transport and logistics } \\
\text { industry, LSP perspective }\end{array}$ \\
\hline & & Corporate compatibility & Lambert et al. (1996) \\
\hline & & Cross-functional collaboration & Fawcett et al. (2008a) \\
\hline
\end{tabular}


Table 7 (continued)

\begin{tabular}{|c|c|c|c|}
\hline General Factor & Enablers/Barriers & Factor & $\begin{array}{l}\text { Paper, Industry and } \\
\text { Perspective }\end{array}$ \\
\hline \multirow[t]{17}{*}{$\begin{array}{l}\text { Presence of } \\
\text { compatibility: Factors } \\
\text { which indicate } \\
\text { complementarities or } \\
\text { not between the } \\
\text { parties in terms of e.g. } \\
\text { goals, culture, } \\
\text { objective and } \\
\text { operating philosophy }\end{array}$} & \multirow[t]{17}{*}{$\begin{array}{l}\text { Presence of } \\
\text { compatibility }\end{array}$} & Cultural compatibility/ fit & $\begin{array}{l}\text { Boddy et al. (2000); Fuller } \\
\text { and Vassie (2002); } \\
\text { Maheshwari et al. (2006); } \\
\text { Maloni and Benton (1997); } \\
\text { Reniers et al. (2010), } \\
\text { chemical industry, shipper } \\
\text { perspective; Visser (2010), } \\
\text { chemical industry, shipper } \\
\text { perspective }\end{array}$ \\
\hline & & Decision synchronization & $\begin{array}{l}\text { Cao and Zhang (2011); } \\
\text { Simatupang and Sridharan } \\
(2002)\end{array}$ \\
\hline & & Exclusivity & Lambert et al. (1996) \\
\hline & & Financial compatibility & $\begin{array}{l}\text { Visser (2010), chemical } \\
\text { industry, shipper } \\
\text { perspective }\end{array}$ \\
\hline & & Fit in human aspects & Maheshwari et al. (2006) \\
\hline & & $\begin{array}{l}\text { Holding end-customer central } \\
\text { (common goal) }\end{array}$ & $\begin{array}{l}* \text {, FMCG industry, LSP } \\
\text { perspective }\end{array}$ \\
\hline & & Incentive alignment & $\begin{array}{l}\text { Cao and Zhang (2011); } \\
\text { Simatupang and Sridharan } \\
\text { (2002) }\end{array}$ \\
\hline & & Integrity and corporative culture & $\begin{array}{l}\text { Cruijssen et al. (2007), } \\
\text { transport and logistics } \\
\text { industry, LSP perspective }\end{array}$ \\
\hline & & Internal alignment & Min et al. (2005) \\
\hline & & $\begin{array}{l}\text { Level of being } \\
\text { supplementary/complementary }\end{array}$ & $\begin{array}{l}\text { Reniers et al. (2010), } \\
\text { chemical industry, shipper } \\
\text { perspective }\end{array}$ \\
\hline & & Management compatibility & $\begin{array}{l}\text { Lambert et al. (1996); } \\
\text { Maloni and Benton (1997) }\end{array}$ \\
\hline & & Objective alignment & $\begin{array}{l}\text { Beach et al. (2005), } \\
\text { construction industry, } \\
\text { manufacturer perspective; } \\
\text { Fawcett et al. (2008b) }\end{array}$ \\
\hline & & Operational compatibility & $\begin{array}{l}\text { Niderkofler (1991); Ryu et } \\
\text { al. (2009) }\end{array}$ \\
\hline & & Organizational compatibility & $\begin{array}{l}\text { Ahmad and Ullah (2013), } \\
\text { manufacturer perspective; } \\
\text { Maheshwari et al. (2006); } \\
\text { Min and Zhou (2002); *, } \\
\text { FMCG industry, LSP, } \\
\text { manufacturer and retailer } \\
\text { perspective }\end{array}$ \\
\hline & & Partner compatibility & $\begin{array}{l}\text { Brinkerhoff (2002); } \\
\text { Cruijssen et al. (2007), } \\
\text { transport and logistics } \\
\text { industry, LSP perspective }\end{array}$ \\
\hline & & Partner should be value added & $\begin{array}{l}\text { Ellram (1995), buyer } \\
\text { perspective }\end{array}$ \\
\hline & & $\begin{array}{l}\text { People-compatibility of the people } \\
\text { who are working for the organizations }\end{array}$ & Boddy et al. (2000) \\
\hline
\end{tabular}


Table 7 (continued)

\begin{tabular}{|c|c|c|c|}
\hline General Factor & Enablers/Barriers & Factor & $\begin{array}{l}\text { Paper, Industry and } \\
\text { Perspective }\end{array}$ \\
\hline \multirow{15}{*}{$\begin{array}{l}\text { Presence of } \\
\text { compatibility: Factors } \\
\text { which indicate } \\
\text { complementarities or } \\
\text { not between the } \\
\text { parties in terms of e.g. } \\
\text { goals, culture, } \\
\text { objective and } \\
\text { operating philosophy }\end{array}$} & \multirow[t]{11}{*}{$\begin{array}{l}\text { Presence of } \\
\text { compatibility }\end{array}$} & Physical proximity & $\begin{array}{l}\text { Cruijssen et al. (2007), } \\
\text { transport and logistics } \\
\text { industry, LSP perspective; } \\
\text { Lambert et al. (1996); } \\
\text { Maheshwari et al. (2006); } \\
\text { Maloni and Benton (1997) }\end{array}$ \\
\hline & & $\begin{array}{l}\text { Prior history of working together with } \\
\text { the partner }\end{array}$ & Lambert et al. (1996) \\
\hline & & Select the right partner & $\begin{array}{l}\text { Ellram (1995), buyer } \\
\text { perspective; Fawcett et al. } \\
\text { (2008b); Reniers et al. } \\
\text { (2010), chemical industry, } \\
\text { shipper perspective; } \\
\text { Simatupang and Sridharan } \\
\text { (2002) }\end{array}$ \\
\hline & & Shared competitors & Lambert et al. (1996) \\
\hline & & Shared customer & $\begin{array}{l}\text { Cruijssen et al. (2007), } \\
\text { transport and logistics } \\
\text { industry, LSP perspective }\end{array}$ \\
\hline & & Shared high value end users & Lambert et al. (1996) \\
\hline & & Shared values & $\begin{array}{l}*, \text { FMCG industry, } \\
\text { manufacturer perspective }\end{array}$ \\
\hline & & $\begin{array}{l}\text { Standardizing and integrating } \\
\text { processes }\end{array}$ & Maheshwari et al. (2006) \\
\hline & & Strategic fit & $\begin{array}{l}\text { Cruijssen et al. (2007), } \\
\text { transport and logistics } \\
\text { industry, LSP perspective; } \\
\text { Niderkofler (1991); Ryu et } \\
\text { al. (2009); }{ }^{*} \text {, FMCG } \\
\text { industry, manufacturer } \\
\text { perspective }\end{array}$ \\
\hline & & $\begin{array}{l}\text { Symmetry: in terms of importance of } \\
\text { each firm to the other's success, } \\
\text { relative size, market share, financial } \\
\text { strength, productivity, brand image, } \\
\text { party reputation and level of } \\
\text { technological satisfaction }\end{array}$ & Lambert et al. (1996) \\
\hline & & Vendor-managed inventory & Fawcett et al. (2008a) \\
\hline & \multirow[t]{4}{*}{ Lack of compatibility } & Cultural differences & $\begin{array}{l}\text { Lambert et al. (1999), } \\
\text { manufacturer and third } \\
\text { party logistics provider } \\
\text { perspective, LSP } \\
\text { perspective; Visser (2010), } \\
\text { logistics outsourcing, } \\
\text { shipper perspective }\end{array}$ \\
\hline & & Differences in interest & $\begin{array}{l}\text { Cruijssen et al. (2007), } \\
\text { transport and logistics } \\
\text { industry, LSP perspective }\end{array}$ \\
\hline & & $\begin{array}{l}\text { Differences in perceptions of reality } \\
\text { used in joint decision making }\end{array}$ & $\begin{array}{l}\text { Simatupang and Sridharan } \\
\text { (2002) }\end{array}$ \\
\hline & & $\begin{array}{l}\text { Different sectors have different } \\
\text { challenges }\end{array}$ & Walker et al. (2008) \\
\hline
\end{tabular}


Table 7 (continued)

\begin{tabular}{|c|c|c|c|}
\hline General Factor & Enablers/Barriers & Factor & $\begin{array}{l}\text { Paper, Industry and } \\
\text { Perspective }\end{array}$ \\
\hline \multirow{16}{*}{$\begin{array}{l}\text { Presence of } \\
\text { compatibility: Factors } \\
\text { which indicate } \\
\text { complementarities or } \\
\text { not between the } \\
\text { parties in terms of e.g. } \\
\text { goals, culture, } \\
\text { objective and } \\
\text { operating philosophy }\end{array}$} & \multirow[t]{16}{*}{ Lack of compatibility } & $\begin{array}{l}\text { Difficulty in finding the right partner to } \\
\text { collaborate with }\end{array}$ & $\begin{array}{l}\text { Cruijssen et al. (2007), } \\
\text { transport and logistics } \\
\text { industry, LSP perspective; } \\
\text { Visser (2010), chemical } \\
\text { industry and logistics } \\
\text { collaboration, shipper } \\
\text { perspective }\end{array}$ \\
\hline & & $\begin{array}{l}\text { Disagreement over the domain of } \\
\text { decisions }\end{array}$ & $\begin{array}{l}\text { Cruijssen et al. (2007), } \\
\text { transport and logistics } \\
\text { industry, LSP perspective; } \\
\text { Simatupang and Sridharan } \\
\text { (2002) }\end{array}$ \\
\hline & & $\begin{array}{l}\text { Firms' way of managing their } \\
\text { businesses are widely different and } \\
\text { clash }\end{array}$ & Niderkofler (1991) \\
\hline & & $\begin{array}{l}\text { Focus on cost reduction at expense of } \\
\text { green practices }\end{array}$ & Walker et al. (2008) \\
\hline & & Inconsistent operating goal & Fawcett et al. (2008a) \\
\hline & & $\begin{array}{l}\text { It is not possible to give smaller } \\
\text { supplier a fixed time window since } \\
\text { they are delivering combined /small } \\
\text { drop sizes }\end{array}$ & $\begin{array}{l}*, \text { FMCG industry, retailer } \\
\text { perspective }\end{array}$ \\
\hline & & Lack of compatible strategic direction & Lambert et al. (1999) \\
\hline & & $\begin{array}{l}\text { Limited number of LSPs who are able } \\
\text { to transport chilled and fresh goods }\end{array}$ & $\begin{array}{l}*, \text { FMCG industry, } \\
\text { manufacturer perspective }\end{array}$ \\
\hline & & $\begin{array}{l}\text { Limited number of LSPs that are } \\
\text { suitable for FTL consolidation }\end{array}$ & $\begin{array}{l}*, \text { FMCG industry, retailer } \\
\text { perspective }\end{array}$ \\
\hline & & $\begin{array}{l}\text { Limited number of manufacturers that } \\
\text { are using the software }\end{array}$ & $\begin{array}{l}*, \text { FMCG industry, LSP } \\
\text { perspective }\end{array}$ \\
\hline & & $\begin{array}{l}\text { Limited number of suppliers and } \\
\text { manufacturers that are able to deliver } \\
\text { with chain conveyer systems in the } \\
\text { truck }\end{array}$ & $\begin{array}{l}\text { *, FMCG industry, LSP } \\
\text { perspective }\end{array}$ \\
\hline & & No common goals & $\begin{array}{l}\text { Lambert et al. (1999), } \\
\text { manufacturer and third } \\
\text { party logistics provider } \\
\text { perspective }\end{array}$ \\
\hline & & Non-aligned policies & $\begin{array}{l}{ }^{*}, \text { FMCG industry, LSP and } \\
\text { manufacturer perspective }\end{array}$ \\
\hline & & No strategic fit & $\begin{array}{l}\text { Fawcett et al. (2008b); } \\
\text { Niderkofler (1991) }\end{array}$ \\
\hline & & Objective differences & $\begin{array}{l}\text { Simatupang and Sridharan } \\
\text { (2002) }\end{array}$ \\
\hline & & Operating differences & $\begin{array}{l}\text { Fawcett et al. (2008b); } \\
\text { Niderkofler (1991) }\end{array}$ \\
\hline
\end{tabular}


Table 7 (continued)

\begin{tabular}{|c|c|c|c|}
\hline General Factor & Enablers/Barriers & Factor & $\begin{array}{l}\text { Paper, Industry and } \\
\text { Perspective }\end{array}$ \\
\hline \multirow[t]{7}{*}{$\begin{array}{l}\text { Presence of } \\
\text { compatibility: Factors } \\
\text { which indicate } \\
\text { complementarities or } \\
\text { not between the } \\
\text { parties in terms of e.g. } \\
\text { goals, culture, } \\
\text { objective and } \\
\text { operating philosophy }\end{array}$} & \multirow[t]{7}{*}{ Lack of compatibility } & Power of a party & $\begin{array}{l}\text { Boddy et al. (2000); } \\
\text { Cruijssen et al. (2007), } \\
\text { transport and logistics } \\
\text { industry, LSP perspective; } \\
\text { Lambert et al. (1999), } \\
\text { manufacturer and third } \\
\text { party logistics provider } \\
\text { perspective; Visser (2010), } \\
\text { logistics collaboration; }{ }^{*}, \\
\text { FMCG industry, } \\
\text { manufacturer and retailer } \\
\text { perspective }\end{array}$ \\
\hline & & $\begin{array}{l}\text { Smaller manufacturers/LSPs are not } \\
\text { able to fulfil required technological } \\
\text { standards }\end{array}$ & $\begin{array}{l}\text { *, FMCG industry, retailer } \\
\text { and LSP perspective }\end{array}$ \\
\hline & & $\begin{array}{l}\text { Small number of suppliers - only a } \\
\text { small selection }\end{array}$ & $\begin{array}{l}\text { Walker et al. (2008), } \\
\text { retailer perspective }\end{array}$ \\
\hline & & $\begin{array}{l}\text { Some retailers are not able to } \\
\text { implement standards }\end{array}$ & $\begin{array}{l}\text { *, FMCG industry, LSP and } \\
\text { manufacturer perspective }\end{array}$ \\
\hline & & Supplier has not the right certificates & $\begin{array}{l}\text { *, FMCG industry, retailer } \\
\text { perspective }\end{array}$ \\
\hline & & $\begin{array}{l}\text { Supplier is not willing to label with } \\
\text { specific labels }\end{array}$ & $\begin{array}{l}* \text {, FMCG industry, retailer } \\
\text { perspective }\end{array}$ \\
\hline & & Unrealistic expectations & Lambert et al. (1999) \\
\hline \multirow{2}{*}{$\begin{array}{l}\text { Presence of } \\
\text { confidentiality: } \\
\text { Factors which indicate } \\
\text { the entrustment of } \\
\text { proprietary } \\
\text { information from one } \\
\text { party to another or } \\
\text { not }\end{array}$} & $\begin{array}{l}\text { Presence of } \\
\text { confidentiality }\end{array}$ & Confidentiality & $\begin{array}{l}\text { Brinkerhoff (2002); Visser } \\
\text { (2010), chemical industry, } \\
\text { logistics collaboration, } \\
\text { shipper perspective }\end{array}$ \\
\hline & Lack of confidentiality & Lack of confidentiality & Visser (2010) \\
\hline \multirow{3}{*}{$\begin{array}{l}\text { Presence of } \\
\text { continuous } \\
\text { improvement: Factors } \\
\text { which indicate the } \\
\text { continuous } \\
\text { improvement or not }\end{array}$} & \multirow[t]{2}{*}{$\begin{array}{l}\text { Presence of } \\
\text { continuous } \\
\text { improvement }\end{array}$} & $\begin{array}{l}\text { Continuous evaluation/ improvement } \\
\text { of performance }\end{array}$ & $\begin{array}{l}\text { Beach et al. (2005), } \\
\text { construction industry, } \\
\text { manufacturer perspective }\end{array}$ \\
\hline & & Continuous improvement & $\begin{array}{l}* \text {, FMCG industry, retailer } \\
\text { perspective }\end{array}$ \\
\hline & $\begin{array}{l}\text { Lack of continuous } \\
\text { improvement }\end{array}$ & Evaluating and monitoring problems & $\begin{array}{l}\text { Visser (2010), logistics } \\
\text { collaboration, shipper } \\
\text { perspective }\end{array}$ \\
\hline \multirow{6}{*}{$\begin{array}{l}\text { Presence of contract: } \\
\text { Factors which indicate } \\
\text { the presence or the } \\
\text { lack of available } \\
\text { agreements between } \\
\text { the parties }\end{array}$} & \multirow[t]{5}{*}{ Presence of contract } & Clear guidelines & $\begin{array}{l}\text { Fawcett et al. (2008a); } \\
\text { Niderkofler (1991) }\end{array}$ \\
\hline & & $\begin{array}{l}\text { Develop and document business } \\
\text { principles and procedures and map } \\
\text { back to value proposition }\end{array}$ & Fawcett et al. (2008a) \\
\hline & & Formalization & Min et al. (2005) \\
\hline & & Right contract style & $\begin{array}{l}\text { Cruijssen et al. (2007), } \\
\text { transport and logistics } \\
\text { industry, LSP perspective; } \\
\text { Lambert et al. (1996) }\end{array}$ \\
\hline & & $\begin{array}{l}\text { Upfront agreements in form of } \\
\text { contracts are important }\end{array}$ & $\begin{array}{l}\text { *, FMCG industry, retailer } \\
\text { perspective }\end{array}$ \\
\hline & Lack of contract & Lack of alliance guidelines & Fawcett et al. (2008a) \\
\hline
\end{tabular}


Table 7 (continued)

\begin{tabular}{|c|c|c|c|}
\hline General Factor & Enablers/Barriers & Factor & $\begin{array}{l}\text { Paper, Industry and } \\
\text { Perspective }\end{array}$ \\
\hline \multirow{3}{*}{$\begin{array}{l}\text { Presence of control: } \\
\text { Factors which indicate } \\
\text { the presence and the } \\
\text { lack of control }\end{array}$} & Presence of control & Joint operating controls & Lambert et al. (1996) \\
\hline & \multirow[t]{2}{*}{ Lack of control } & Lack of control & $\begin{array}{l}\text { Cruijssen et al. (2007), } \\
\text { transport and logistics } \\
\text { industry, LSP perspective; } \\
\text { Lambert et al. (1999), } \\
\text { manufacturer and third } \\
\text { party logistics provider } \\
\text { perspective }\end{array}$ \\
\hline & & Loss of control & $\begin{array}{l}\text { Visser (2010), chemical } \\
\text { industry, logistics } \\
\text { collaboration and } \\
\text { outsourcing, shipper } \\
\text { perspective }\end{array}$ \\
\hline \multirow{5}{*}{$\begin{array}{l}\text { Presence of } \\
\text { coordination: Factors } \\
\text { which indicate the } \\
\text { synchronization and } \\
\text { integration of } \\
\text { something or not }\end{array}$} & \multirow{5}{*}{$\begin{array}{l}\text { Presence of } \\
\text { coordination }\end{array}$} & Central coordination & Maloni and Benton (1997) \\
\hline & & Coordination & $\begin{array}{l}\text { Kim et al. (2010), fast } \\
\text { moving global markets; } \\
\text { Mohr and Spekman (1994), } \\
\text { computer industry, dealer } \\
\text { perspective; Riggin et al. } \\
(1992)\end{array}$ \\
\hline & & Process integration & Maloni and Benton (1997) \\
\hline & & Supply integration & Walker et al. (2008) \\
\hline & & System and channel integration & Horvath (2001) \\
\hline \multirow{9}{*}{$\begin{array}{l}\text { Presence of } \\
\text { experiences, skills and } \\
\text { knowledge: Factors } \\
\text { which indicate the } \\
\text { presence or the lack } \\
\text { of experiences, skills } \\
\text { and knowledge of the } \\
\text { parties }\end{array}$} & \multirow{9}{*}{$\begin{array}{l}\text { Presence of } \\
\text { experiences, skills and } \\
\text { knowledge }\end{array}$} & Cultural maturity & Fuller and Vassie (2002) \\
\hline & & Exchange of knowledge & $\begin{array}{l}\text { Beach et al. (2005), } \\
\text { construction industry, } \\
\text { manufacturer perspective; } \\
\text { Cao and Zhang (2011) }\end{array}$ \\
\hline & & External knowledge & $\begin{array}{l}\text { Reniers et al. (2010), } \\
\text { chemical industry, shipper } \\
\text { perspective }\end{array}$ \\
\hline & & Former partnership and experience & $\begin{array}{l}\text { Reniers et al. (2010), } \\
\text { chemical industry, shipper } \\
\text { perspective }\end{array}$ \\
\hline & & $\begin{array}{l}\text { Frequency: occurrence frequency of a } \\
\text { certain transaction }\end{array}$ & $\begin{array}{l}\text { Visser (2010), logistics } \\
\text { collaboration, shipper } \\
\text { perspective }\end{array}$ \\
\hline & & Shared expertise & Fawcett et al. (2008a) \\
\hline & & $\begin{array}{l}\text { Shared learning throughout the } \\
\text { organization and the supply chain }\end{array}$ & Fawcett et al. (2008b) \\
\hline & & Skilful policy entrepreneur & Walker et al. (2008) \\
\hline & & $\begin{array}{l}\text { Step-by-step approach: it is important } \\
\text { to begin with smaller collaboration } \\
\text { projects, if small projects are } \\
\text { successful you can take next step }\end{array}$ & $\begin{array}{l}\text { Niderkofler (1991); }{ }^{*} \\
\text { FMCG industry, retailer } \\
\text { perspective }\end{array}$ \\
\hline \multirow[t]{2}{*}{$\begin{array}{l}\text { Presence of (fair) } \\
\text { benefits: Factors } \\
\text { which indicate the } \\
\text { presence or the lack } \\
\text { of benefits and } \\
\text { whether the benefits } \\
\text { are fair or not }\end{array}$} & \multirow[t]{2}{*}{$\begin{array}{l}\text { Presence of (fair) } \\
\text { benefits }\end{array}$} & Benefits sharing & $\begin{array}{l}\text { Anbanandam et al. (2011), } \\
\text { apparel industry, } \\
\text { manufacturer and retailer } \\
\text { perspective; Ellram (1995), } \\
\text { buyer perspective; Fawcett } \\
\text { et al. (2008a); Lambert et } \\
\text { al. (1996) }\end{array}$ \\
\hline & & High chance of success & $\begin{array}{l}* \text {, FMCG industry, retailer } \\
\text { perspective }\end{array}$ \\
\hline
\end{tabular}


Table 7 (continued)

\begin{tabular}{|c|c|c|c|}
\hline General Factor & Enablers/Barriers & Factor & $\begin{array}{l}\text { Paper, Industry and } \\
\text { Perspective }\end{array}$ \\
\hline \multirow{18}{*}{$\begin{array}{l}\text { Presence of (fair) } \\
\text { benefits: Factors } \\
\text { which indicate the } \\
\text { presence or the lack } \\
\text { of benefits and } \\
\text { whether the benefits } \\
\text { are fair or not }\end{array}$} & \multirow[t]{2}{*}{$\begin{array}{l}\text { Presence of (fair) } \\
\text { benefits }\end{array}$} & Mutual benefits & $\begin{array}{l}\text { Ellram (1995), buyer } \\
\text { perspective; }{ }^{*}, \text { FMCG } \\
\text { industry, manufacturer } \\
\text { perspective }\end{array}$ \\
\hline & & Total costs and profit benefits & Maloni and Benton (1997) \\
\hline & \multirow[t]{16}{*}{ Lack of (fair) benefits } & $\begin{array}{l}\text { Accounting method limit green } \\
\text { reporting }\end{array}$ & Walker et al. (2008) \\
\hline & & Adjustment of entire internal process & $\begin{array}{l}*, \text { FMCG industry, } \\
\text { manufacturer perspective }\end{array}$ \\
\hline & & $\begin{array}{l}\text { Difficulties in determining the } \\
\text { (monetary) benefit }\end{array}$ & $\begin{array}{l}\text { Cruijssen et al. (2007), } \\
\text { transport and logistics } \\
\text { industry, LSP perspective }\end{array}$ \\
\hline & & $\begin{array}{l}\text { Difficulties in establishing a fair } \\
\text { allocation of the benefits }\end{array}$ & $\begin{array}{l}\text { Visser (2010), logistics } \\
\text { collaboration and } \\
\text { outsourcing, shipper } \\
\text { perspective; *, FMCG } \\
\text { industry, retailer } \\
\text { perspective }\end{array}$ \\
\hline & & $\begin{array}{l}\text { Difficulty in establishing a fair } \\
\text { allocation of shared workload }\end{array}$ & $\begin{array}{l}\text { Cruijssen et al. (2007), } \\
\text { transport and logistics } \\
\text { industry, LSP perspective }\end{array}$ \\
\hline & & $\begin{array}{l}\text { Difficulty in establishing fair allocation } \\
\text { of the benefits }\end{array}$ & $\begin{array}{l}\text { Cruijssen et al. (2007), } \\
\text { transport and logistics } \\
\text { industry, LSP perspective }\end{array}$ \\
\hline & & $\begin{array}{l}\text { Lack of buyer awareness for green } \\
\text { SCM }\end{array}$ & Walker et al. (2008) \\
\hline & & $\begin{array}{l}\text { Lack of mutual benefits/ profitability } \\
\text { for either party }\end{array}$ & $\begin{array}{l}\text { Lambert et al. (1999), } \\
\text { manufacturer and third } \\
\text { party logistics provider } \\
\text { perspective; *, FMCG } \\
\text { industry, manufacturer } \\
\text { perspective }\end{array}$ \\
\hline & & Less efficient tour planning & $\begin{array}{l}*, \text { FMCG industry, LSP } \\
\text { perspective }\end{array}$ \\
\hline & & $\begin{array}{l}\text { Limited SCC: there is a doubt, that the } \\
\text { other parties gain more benefits than } \\
\text { the own party }\end{array}$ & $\begin{array}{l}\text { *, FMCG industry, retailer } \\
\text { perspective }\end{array}$ \\
\hline & & No usage of chain conveyer systems & $\begin{array}{l}* \text {, FMCG industry, retailer } \\
\text { perspective }\end{array}$ \\
\hline & & $\begin{array}{l}\text { Reverse logistics/ loading of return } \\
\text { goods has no priority - waste of time }\end{array}$ & $\begin{array}{l}* \text {, FMCG industry, retailer } \\
\text { perspective }\end{array}$ \\
\hline & & $\begin{array}{l}\text { Some suppliers still strive to deliver } \\
\text { their own FTL with one order and not } \\
\text { considered FTL with different orders }\end{array}$ & $\begin{array}{l}*, \text { FMCG industry, retailer } \\
\text { perspective }\end{array}$ \\
\hline & & Strategic benefits unclear & $\begin{array}{l}\text { Akintoye et al. (2000), } \\
\text { construction industry, } \\
\text { manufacturer perspective }\end{array}$ \\
\hline & & Unfairness in cost and pricing & $\begin{array}{l}\text { Lambert et al. (1999), } \\
\text { manufacturer and third } \\
\text { party logistics provider } \\
\text { perspective }\end{array}$ \\
\hline & & Use of software less efficient & $\begin{array}{l}*, \text { FMCG industry, LSP } \\
\text { perspective and retailer } \\
\text { perspective }\end{array}$ \\
\hline
\end{tabular}


Table 7 (continued)

\begin{tabular}{|c|c|c|c|}
\hline General Factor & Enablers/Barriers & Factor & $\begin{array}{l}\text { Paper, Industry and } \\
\text { Perspective }\end{array}$ \\
\hline \multirow{4}{*}{$\begin{array}{l}\text { Presence of flexibility: } \\
\text { Factors which indicate } \\
\text { the presence or the } \\
\text { lack of flexibility }\end{array}$} & \multirow[t]{2}{*}{ Presence of flexibility } & External flexibility & $\begin{array}{l}\text { Reniers et al. (2010), } \\
\text { chemical industry, shipper } \\
\text { perspective }\end{array}$ \\
\hline & & Flexibility & $\begin{array}{l}\text { Maloni and Benton (1997); } \\
\text { Niderkofler (1991); Visser } \\
\text { (2010), chemical industry, } \\
\text { shipper perspective }\end{array}$ \\
\hline & \multirow[t]{2}{*}{ Lack of flexibility } & $\begin{array}{l}\text { Failure to respond to changes in } \\
\text { corporate strategy/ market condition }\end{array}$ & $\begin{array}{l}\text { Lambert et al. (1999), } \\
\text { manufacturer and third } \\
\text { party logistics provider } \\
\text { perspective }\end{array}$ \\
\hline & & $\begin{array}{l}\text { Limited usage of trucks with chain } \\
\text { conveyer systems - less flexible }\end{array}$ & $\begin{array}{l}*, \text { FMCG industry, LSP } \\
\text { perspective }\end{array}$ \\
\hline $\begin{array}{l}\text { Presence of goodwill: } \\
\text { Factors which indicate } \\
\text { the presence or the } \\
\text { lack of value of e. g. a } \\
\text { party }\end{array}$ & Presence of goodwill & Goodwill & $\begin{array}{l}\text { Maloni and Benton (1997); } \\
\text { Niderkofler (1991); }{ }^{*}, \\
\text { FMCG industry, retailer } \\
\text { perspective }\end{array}$ \\
\hline \multirow{3}{*}{$\begin{array}{l}\text { Presence of } \\
\text { interaction: Factors } \\
\text { which indicate the } \\
\text { presence or a lack of } \\
\text { interaction }\end{array}$} & \multirow{3}{*}{$\begin{array}{l}\text { Presence of } \\
\text { interaction }\end{array}$} & Intensive interaction & Maloni and Benton (1997) \\
\hline & & Interpersonal interaction & $\begin{array}{l}\text { Visser (2010), logistics } \\
\text { collaboration, shipper } \\
\text { perspective }\end{array}$ \\
\hline & & Senior management interaction & Fawcett et al. (2008b) \\
\hline \multirow[t]{3}{*}{$\begin{array}{l}\text { Presence of } \\
\text { interdependence: } \\
\text { Factors which indicate } \\
\text { the presence or the } \\
\text { lack of a reciprocal } \\
\text { relation between } \\
\text { independent parties }\end{array}$} & \multirow[t]{3}{*}{$\begin{array}{l}\text { Presence of } \\
\text { interdependence }\end{array}$} & Interdependence & $\begin{array}{l}\text { Ahmad and Ullah (2013), } \\
\text { manufacturer perspective; } \\
\text { Cruijssen et al. (2007), } \\
\text { transport and logistics } \\
\text { industry, LSP perspective; } \\
\text { Heikkilä (2002), } \\
\text { telecommunication } \\
\text { industry; Ryu et al. (2009); } \\
\text { Simatupang and Sridharan } \\
\text { (2002); * FMCG industry, } \\
\text { LSP, manufacturer and } \\
\text { retailer perspective }\end{array}$ \\
\hline & & Mutual help & $\begin{array}{l}\text { Cruijssen et al. (2007), } \\
\text { transport and logistics } \\
\text { industry, LSP perspective }\end{array}$ \\
\hline & & Mutuality & $\begin{array}{l}\text { Barrat (2004); Lambert et } \\
\text { al. (1999), manufacturer } \\
\text { and third party logistics } \\
\text { provider perspective }\end{array}$ \\
\hline \multirow[b]{2}{*}{$\begin{array}{l}\text { Presence of } \\
\text { leadership: Factors } \\
\text { which indicate the } \\
\text { presence or the lack } \\
\text { of leadership }\end{array}$} & \multirow{2}{*}{$\begin{array}{l}\text { Presence of } \\
\text { leadership }\end{array}$} & Existence of partnership champion & Brinkerhoff (2002) \\
\hline & & Leadership & $\begin{array}{l}\text { Ahmad and Ullah (2013), } \\
\text { manufacturer perspective; } \\
\text { Cruijssen et al. (2007), } \\
\text { transport and logistics } \\
\text { industry, LSP perspective; } \\
\text { Kim et al. (2010), fast } \\
\text { moving global markets; } \\
\text { Perry and Sohal (2001), } \\
\text { textiles, clothing and foot } \\
\text { wear industry; Riggin et al. } \\
\text { (1992) }\end{array}$ \\
\hline
\end{tabular}


Table 7 (continued)

\begin{tabular}{|c|c|c|c|}
\hline General Factor & Enablers/Barriers & Factor & $\begin{array}{l}\text { Paper, Industry and } \\
\text { Perspective }\end{array}$ \\
\hline \multirow{4}{*}{$\begin{array}{l}\text { Presence of long-term } \\
\text { relationship: Factors } \\
\text { which indicate the } \\
\text { presence or the lack } \\
\text { of a long-term } \\
\text { relationships }\end{array}$} & \multirow[t]{3}{*}{$\begin{array}{l}\text { Presence of long-term } \\
\text { relationship }\end{array}$} & Duration of the relationship & $\begin{array}{l}\text { Heikkilä (2002), } \\
\text { telecommunication } \\
\text { industry }\end{array}$ \\
\hline & & Long-term process & $\begin{array}{l}\text { Akintoye et al. (2000), } \\
\text { construction industry, } \\
\text { manufacturer perspective }\end{array}$ \\
\hline & & Long-term relationship & $\begin{array}{l}\text { Anbanandam et al. (2011), } \\
\text { apparel retail industry, } \\
\text { manufacturer and retailer } \\
\text { perspective }\end{array}$ \\
\hline & $\begin{array}{l}\text { Lack of long-term } \\
\text { relationship }\end{array}$ & Short-term relationship & $\begin{array}{l}\text { Niderkofler (1991); }{ }^{*}, \\
\text { FMCG industry, } \\
\text { manufacturer perspective }\end{array}$ \\
\hline \multirow{3}{*}{$\begin{array}{l}\text { Presence of } \\
\text { neglecting money in } \\
\text { the first meeting: } \\
\text { Factors which indicate } \\
\text { the need to do not } \\
\text { talk about money in } \\
\text { the first meeting }\end{array}$} & $\begin{array}{l}\text { Presence of neglecting } \\
\text { money in the first } \\
\text { meeting }\end{array}$ & Neglecting money in the first meeting & $\begin{array}{l}\text { *, FMCG industry, } \\
\text { manufacturer, retailer and } \\
\text { LSP perspective }\end{array}$ \\
\hline & \multirow{2}{*}{$\begin{array}{l}\text { Lack of neglecting in } \\
\text { the first meeting } \\
\text { money }\end{array}$} & $\begin{array}{l}\text { Fair gain sharing always discussion if } \\
\text { money is involved }\end{array}$ & $\begin{array}{l}*, \text { FMCG industry, LSP } \\
\text { perspective }\end{array}$ \\
\hline & & $\begin{array}{l}\text { Speaking about gain sharing very } \\
\text { complex }\end{array}$ & $\begin{array}{l}* \text {, FMCG industry, LSP and } \\
\text { manufacturer perspective }\end{array}$ \\
\hline $\begin{array}{l}\text { Presence of no } \\
\text { opportunistic } \\
\text { behaviour: Factors } \\
\text { which indicate the } \\
\text { presence or absence } \\
\text { of opportunistic } \\
\text { behaviour }\end{array}$ & $\begin{array}{l}\text { Lack of no } \\
\text { opportunistic } \\
\text { behaviour }\end{array}$ & Opportunistic behaviour & $\begin{array}{l}\text { Cruijssen et al. (2007), } \\
\text { transport and logistics } \\
\text { industry, LSP perspective; } \\
\text { Lambert et al. (1999), } \\
\text { manufacturer and third } \\
\text { party logistics provider } \\
\text { perspective; Visser (2010), } \\
\text { logistics outsourcing, } \\
\text { shipper perspective }\end{array}$ \\
\hline \multirow{4}{*}{$\begin{array}{l}\text { Presence of partner } \\
\text { contribution: Factors } \\
\text { which indicate the } \\
\text { presence or the lack } \\
\text { of doing something in } \\
\text { order to achieve } \\
\text { something with other } \\
\text { people or to make it } \\
\text { successful }\end{array}$} & \multirow[t]{3}{*}{$\begin{array}{l}\text { Presence of partner } \\
\text { contribution }\end{array}$} & Contribution of other parties & $\begin{array}{l}* \text {, FMCG industry, LSP } \\
\text { perspective }\end{array}$ \\
\hline & & Involvement of the parties & $\begin{array}{l}\text { Beach et al. (2005), } \\
\text { construction industry, } \\
\text { manufacturer perspective; } \\
\text { Walker et al. (2008) }\end{array}$ \\
\hline & & Partner contribution & $\begin{array}{l}\text { Ellram (1995), buyer } \\
\text { perspective }\end{array}$ \\
\hline & $\begin{array}{l}\text { Lack of partner } \\
\text { contribution }\end{array}$ & $\begin{array}{l}\text { No involvement of subsequent liaison } \\
\text { manager }\end{array}$ & Niderkofler (1991) \\
\hline \multirow{4}{*}{$\begin{array}{l}\text { Presence of planning: } \\
\text { Factors which indicate } \\
\text { the presence or the } \\
\text { lack of deciding how } \\
\text { to do something }\end{array}$} & \multirow[t]{2}{*}{ Presence of planning } & Joint business planning & $\begin{array}{l}\text { Akintoye et al. (2000), } \\
\text { construction industry, } \\
\text { manufacturer perspective }\end{array}$ \\
\hline & & Planning & $\begin{array}{l}\text { Lambert et al. (1996); } \\
\text { Riggin et al. (1992) }\end{array}$ \\
\hline & \multirow[t]{2}{*}{ Lack of planning } & Poor upfront planning & Lambert et al. (1996) \\
\hline & & Internal planning failure & Richey et al. (2009) \\
\hline $\begin{array}{l}\text { Presence of } \\
\text { reliability: Factors } \\
\text { which indicate } \\
\text { whether something is } \\
\text { working or not }\end{array}$ & Presence of reliability & Reliability of supply & $\begin{array}{l}\text { Akintoye et al. (2000), } \\
\text { construction industry, } \\
\text { manufacturer perspective }\end{array}$ \\
\hline
\end{tabular}


Table 7 (continued)

\begin{tabular}{|c|c|c|c|}
\hline General Factor & Enablers/Barriers & Factor & $\begin{array}{l}\text { Paper, Industry and } \\
\text { Perspective }\end{array}$ \\
\hline \multirow{13}{*}{$\begin{array}{l}\text { Presence of } \\
\text { resources: Factors } \\
\text { which indicate the } \\
\text { presence or the } \\
\text { absence of a useful or } \\
\text { valuable possession or } \\
\text { quality of e. g. a party }\end{array}$} & \multirow[t]{9}{*}{ Presence of resources } & $\begin{array}{l}\text { Availability and quality of nonfinancial } \\
\text { resources }\end{array}$ & Riggin et al. (1992) \\
\hline & & External financial position & $\begin{array}{l}\text { Reniers et al. (2010), } \\
\text { chemical industry, shipper } \\
\text { perspective }\end{array}$ \\
\hline & & External innovation potential & $\begin{array}{l}\text { Reniers et al. (2010), } \\
\text { chemical industry, shipper } \\
\text { perspective }\end{array}$ \\
\hline & & Financial resources & $\begin{array}{l}\text { Boddy et al. (2000); Maloni } \\
\text { and Benton (1997); Riggin } \\
\text { et al. (1992) }\end{array}$ \\
\hline & & Management of resources & Riggin et al. (1992) \\
\hline & & Manpower development & $\begin{array}{l}\text { Akintoye et al. (2000), } \\
\text { construction industry, } \\
\text { manufacturer perspective }\end{array}$ \\
\hline & & $\begin{array}{l}\text { Open, low-costs connectivity [smaller } \\
\text { parties must be able to success a SCC } \\
\text { without major investments in } \\
\text { proprietary technology] }\end{array}$ & Horvath (2001) \\
\hline & & Resources & Barrat (2004) \\
\hline & & Shared resources & Cao and Zhang (2011) \\
\hline & \multirow[t]{4}{*}{ Lack of resources } & $\begin{array}{l}\text { A lot of work required for } \\
\text { implementation }\end{array}$ & $\begin{array}{l}*, \text { FMCG, industry, } \\
\text { manufacturer perspective }\end{array}$ \\
\hline & & Lack of resources & $\begin{array}{l}\text { Fawcett et al. (2008b); } \\
\text { Niderkofler (1991); Walker } \\
\text { et al. (2008), retailer } \\
\text { perspective }\end{array}$ \\
\hline & & No capacity of manpower to start SCC & $\begin{array}{l}\text { Maloni and Benton (1997); } \\
\text { *, FMCG industry, retailer } \\
\text { perspective }\end{array}$ \\
\hline & & Not enough time and energy & $\begin{array}{l}*, \text { FMCG industry, LSP and } \\
\text { retailer perspective }\end{array}$ \\
\hline \multirow{5}{*}{$\begin{array}{l}\text { Presence of right } \\
\text { contact person: } \\
\text { Factors which indicate } \\
\text { the presence of the } \\
\text { absence of a } \\
\text { compatible contact } \\
\text { person }\end{array}$} & $\begin{array}{l}\text { Presence of right } \\
\text { contact person }\end{array}$ & Relation to contact person & $\begin{array}{l}*, \text { FMCG industry, } \\
\text { manufacturer, LSP and } \\
\text { retailer perspective }\end{array}$ \\
\hline & \multirow[t]{4}{*}{$\begin{array}{l}\text { Lack of right contact } \\
\text { person }\end{array}$} & Commercial vs. logistics & $\begin{array}{l}*, \text { FMCG industry, } \\
\text { manufacturer perspective }\end{array}$ \\
\hline & & Inappropriate liaison managers & Niderkofler (1991) \\
\hline & & $\begin{array}{l}\text { SCM vs. commercial (different ways of } \\
\text { thinking) }\end{array}$ & $\begin{array}{l}*, \text { FMCG industry, } \\
\text { manufacturer and retailer } \\
\text { perspective }\end{array}$ \\
\hline & & Wrong contact person & $\begin{array}{l}*, \text { FMCG industry, } \\
\text { manufacturer perspective }\end{array}$ \\
\hline $\begin{array}{l}\text { Presence of risk } \\
\text { sharing: Factors } \\
\text { which indicate the } \\
\text { presence or the lack } \\
\text { of risk sharing }\end{array}$ & $\begin{array}{l}\text { Presence of risk } \\
\text { sharing }\end{array}$ & Risk sharing & $\begin{array}{l}\text { Anbanandam et al. (2011), } \\
\text { apparel industry, } \\
\text { manufacturer and retailer } \\
\text { perspective; Beach et al. } \\
\text { (2005), construction } \\
\text { industry, manufacturer } \\
\text { perspective; Ellram (1995), } \\
\text { buyer perspective; Fawcett } \\
\text { et al. (2008a); Lambert et } \\
\text { al. (1996) }\end{array}$ \\
\hline
\end{tabular}


Table 7 (continued)

\begin{tabular}{|c|c|c|c|}
\hline General Factor & Enablers/Barriers & Factor & $\begin{array}{l}\text { Paper, Industry and } \\
\text { Perspective }\end{array}$ \\
\hline $\begin{array}{l}\text { Presence of risk } \\
\text { sharing: Factors } \\
\text { which indicate the } \\
\text { presence or the lack } \\
\text { of risk sharing }\end{array}$ & Lack of risk sharing & Lack of willingness to share risk & $\begin{array}{l}\text { Fawcett et al. (2008a); } \\
\text { Fawcett et al. (2008b) }\end{array}$ \\
\hline \multirow{2}{*}{$\begin{array}{l}\text { Presence of time: } \\
\text { Factors which indicate } \\
\text { the presence or the } \\
\text { absence of enough } \\
\text { time }\end{array}$} & \multirow[t]{2}{*}{ Presence of time } & $\begin{array}{l}\text { Factor time: start the SCC to the right } \\
\text { time }\end{array}$ & $\begin{array}{l}\text { *, FMCG industry, retailer } \\
\text { perspective }\end{array}$ \\
\hline & & $\begin{array}{l}\text { No time pressure at the negotiation } \\
\text { process }\end{array}$ & Niderkofler (1991) \\
\hline \multirow[b]{2}{*}{$\begin{array}{l}\text { Presence of tolerance: } \\
\text { Factors which indicate } \\
\text { the presence or the } \\
\text { absence of the } \\
\text { willingness to accept } \\
\text { behaviour and beliefs } \\
\text { which are different } \\
\text { from your own }\end{array}$} & \multirow[t]{2}{*}{ Presence of tolerance } & High degree of tolerance & Niderkofler (1991) \\
\hline & & Tolerance to share power & Brinkerhoff (2002) \\
\hline \multirow[t]{11}{*}{$\begin{array}{l}\text { Presence of tools: } \\
\text { Factors which indicate } \\
\text { the presence or the } \\
\text { lack of e. g. methods } \\
\text { and measurements } \\
\text { which helps to start } \\
\text { the SCC }\end{array}$} & \multirow[t]{11}{*}{ Presence of tools } & $\begin{array}{l}\text { Conflict resolution techniques/ } \\
\text { management }\end{array}$ & $\begin{array}{l}\text { Beach et al. (2005), } \\
\text { construction industry, } \\
\text { manufacturer perspective; } \\
\text { Brinkerhoff (2002); } \\
\text { Cruijssen et al. (2007), } \\
\text { transport and logistics } \\
\text { industry, LSP perspective; } \\
\text { Kim et al. (2010), fast } \\
\text { moving global markets; } \\
\text { Maloni and Benton (1997) }\end{array}$ \\
\hline & & Demonstrating the business case & Barrat (2004) \\
\hline & & $\begin{array}{l}\text { Design a proactive supplier scorecard- } \\
\text { based rating system to drive } \\
\text { continuous improvement }\end{array}$ & Fawcett et al. (2008b) \\
\hline & & Dispute resolution planning & $\begin{array}{l}\text { Beach et al. (2005), } \\
\text { construction industry, } \\
\text { manufacturer perspective }\end{array}$ \\
\hline & & Documentation & Maloni and Benton (1997) \\
\hline & & Education and training & $\begin{array}{l}\text { Beach et al. (2005), } \\
\text { construction industry, } \\
\text { manufacturer perspective }\end{array}$ \\
\hline & & $\begin{array}{l}\text { Establish a supplier development } \\
\text { program via process improvement and } \\
\text { product development teams }\end{array}$ & Fawcett et al. (2008b) \\
\hline & & $\begin{array}{l}\text { Establish performance measurements, } \\
\text { that leads to cooperation and create } \\
\text { visibility }\end{array}$ & Fawcett et al. (2008b) \\
\hline & & Integrated teams & $\begin{array}{l}\text { Beach et al. (2005), } \\
\text { construction industry, } \\
\text { manufacturer perspective }\end{array}$ \\
\hline & & Joint problem solving & $\begin{array}{l}\text { Mohr and Spekman (1994), } \\
\text { computer industry, dealer } \\
\text { perspective }\end{array}$ \\
\hline & & More frequent meetings & $\begin{array}{l}\text { Akintoye et al. (2000), } \\
\text { construction industry, } \\
\text { manufacturer perspective }\end{array}$ \\
\hline
\end{tabular}


Table 7 (continued)

\begin{tabular}{|c|c|c|c|}
\hline General Factor & Enablers/Barriers & Factor & $\begin{array}{l}\text { Paper, Industry and } \\
\text { Perspective }\end{array}$ \\
\hline \multirow{19}{*}{$\begin{array}{l}\text { Presence of tools: } \\
\text { Factors which indicate } \\
\text { the presence or the } \\
\text { lack of e. g. methods } \\
\text { and measurements } \\
\text { which helps to start } \\
\text { the SCC }\end{array}$} & \multirow[t]{12}{*}{ Presence of tools } & Partnering workshop & $\begin{array}{l}\text { Beach et al. (2005), } \\
\text { construction industry, } \\
\text { manufacturer perspective }\end{array}$ \\
\hline & & Perception and needs analysis & Maloni and Benton (1997) \\
\hline & & Preparation of staff & $\begin{array}{l}\text { Beach et al. (2005), } \\
\text { construction industry, } \\
\text { manufacturer perspective }\end{array}$ \\
\hline & & Right performance measurements & Maloni and Benton (1997) \\
\hline & & $\begin{array}{l}\text { Supply chain mapping to develop a } \\
\text { holistic view }\end{array}$ & Fawcett et al. (2008b) \\
\hline & & $\begin{array}{l}\text { Supply chain training throughout the } \\
\text { organization/supply chain }\end{array}$ & $\begin{array}{l}\text { Fawcett et al. (2008a); } \\
\text { Fawcett et al. (2008b) }\end{array}$ \\
\hline & & Use cross-functional teams & $\begin{array}{l}\text { Fawcett et al. (2008a); } \\
\text { Fawcett et al. (2008b) }\end{array}$ \\
\hline & & Use of activity based costing & $\begin{array}{l}\text { Fawcett et al. (2008a); Min } \\
\text { and Zhou (2002) }\end{array}$ \\
\hline & & Use of consistent measurements & Fawcett et al. (2008a) \\
\hline & & Use of supply chain measurements & Fawcett et al. (2008a) \\
\hline & & Use of total cost analysis & Fawcett et al. (2008a) \\
\hline & & Use supply chain teams & Fawcett et al. (2008a) \\
\hline & \multirow[t]{7}{*}{ Lack of tools } & $\begin{array}{l}\text { Cross functional conflicts and "turf"- } \\
\text { protection }\end{array}$ & Fawcett et al. (2008b) \\
\hline & & External monitoring failure & Richey et al. (2009) \\
\hline & & Lack of training & $\begin{array}{l}\text { Fawcett et al. (2008b); } \\
\text { Walker et al. (2008) }\end{array}$ \\
\hline & & $\begin{array}{l}\text { No measurements of customer } \\
\text { demand }\end{array}$ & Fawcett et al. (2008a) \\
\hline & & $\begin{array}{l}\text { No measurements of supply chain } \\
\text { contribution }\end{array}$ & Fawcett et al. (2008a) \\
\hline & & Non-aligned measures & $\begin{array}{l}\text { Fawcett et al. (2008a); } \\
\text { Fawcett et al. (2008b); } \\
\text { Richey et al. (2009) }\end{array}$ \\
\hline & & Partners' interests conflict & Niderkofler (1991) \\
\hline \multirow{5}{*}{$\begin{array}{l}\text { Presence of } \\
\text { transparency and } \\
\text { openness: Factors } \\
\text { which indicate the } \\
\text { presence or the } \\
\text { absence of } \\
\text { transparency and } \\
\text { openness }\end{array}$} & \multirow{5}{*}{$\begin{array}{l}\text { Presence of } \\
\text { transparency and } \\
\text { openness }\end{array}$} & Honesty & $\begin{array}{l}\text { Barrat (2004); }{ }^{*}, \text { FMCG } \\
\text { industry, LSP perspective }\end{array}$ \\
\hline & & Open book-policy and transparency & $\begin{array}{l}\text { Cruijssen et al. (2007), } \\
\text { transport and logistics } \\
\text { industry, LSP perspective }\end{array}$ \\
\hline & & Open-minded & $\begin{array}{l}*, \text { FMCG industry, retailer } \\
\text { perspective }\end{array}$ \\
\hline & & Openness & $\begin{array}{l}\text { Barrat (2004); Ellram } \\
\text { (1995), buyer perspective; } \\
\text { Reniers et al. (2010), } \\
\text { chemical industry, shipper } \\
\text { perspective; }{ }^{*}, \text { FMCG } \\
\text { industry, retailer and } \\
\text { manufacturer perspective }\end{array}$ \\
\hline & & Transparency & $\begin{array}{l}\text { Visser (2010), logistics } \\
\text { collaboration, shipper } \\
\text { perspective*, FMCG } \\
\text { industry, retailer, } \\
\text { manufacturer and LSP } \\
\text { perspective }\end{array}$ \\
\hline
\end{tabular}


Table 7 (continued)

\begin{tabular}{|c|c|c|c|}
\hline General Factor & Enablers/Barriers & Factor & $\begin{array}{l}\text { Paper, Industry and } \\
\text { Perspective }\end{array}$ \\
\hline $\begin{array}{l}\text { Presence of } \\
\text { transparency and } \\
\text { openness: Factors } \\
\text { which indicate the } \\
\text { presence or the } \\
\text { absence of } \\
\text { transparency and } \\
\text { openness }\end{array}$ & $\begin{array}{l}\text { Lack of transparency } \\
\text { and openness }\end{array}$ & Lack of transparency & $\begin{array}{l}*, \text { FMCG industry, } \\
\text { manufacturer perspective }\end{array}$ \\
\hline \multirow[t]{3}{*}{$\begin{array}{l}\text { Presence of trust: } \\
\text { Factors which indicate } \\
\text { the presence or the } \\
\text { lack of partners } \\
\text { perceive each other as } \\
\text { credible and } \\
\text { benevolent }\end{array}$} & \multirow[t]{2}{*}{ Presence of trust } & Trust & $\begin{array}{l}\text { Ahmad and Ullah (2013), } \\
\text { manufacturer perspective; } \\
\text { Akintoye et al. (2000); } \\
\text { Anbanandam et al. (2011), } \\
\text { apparel industry, retailer } \\
\text { and manufacturer } \\
\text { perspective; Barrat (2004); } \\
\text { Beach et al. (2005); Boddy } \\
\text { et al. (2000); Cruijssen et al. } \\
\text { (2007), transport and } \\
\text { logistics industry, LSP } \\
\text { perspective; Ellram (1995), } \\
\text { buyer perspective; Fawcett } \\
\text { et al. (2008b); Fuller and } \\
\text { Vassie (2002), industry with } \\
\text { safety culture; Heikkilä } \\
\text { (2002); Kim et al. (2010), } \\
\text { fast moving global markets; } \\
\text { Lambert et al. (1996); Min } \\
\text { et al. (2005); Min and Zhou } \\
\text { (2002); Mohr and Spekman } \\
\text { (1994), computer industry, } \\
\text { dealer perspective; } \\
\text { Niderkofler (1991); Perry } \\
\text { and Sohal (2001), textiles, } \\
\text { clothing and foot wear } \\
\text { industry; Reniers et al. } \\
\text { (2010), chemical industry, } \\
\text { shipper perspective; Ryu et } \\
\text { al. (2009); Visser (2010), } \\
\text { chemical industry and } \\
\text { logistics collaboration, } \\
\text { shipper perspective; *, } \\
\text { FMcG industry, LSP, } \\
\text { manufacturer and retailer } \\
\text { perspective }\end{array}$ \\
\hline & & Mutual trust & $\begin{array}{l}\text { Ellram (1995), buyer } \\
\text { perspective; Maheshwari et } \\
\text { al. (2006) }\end{array}$ \\
\hline & Lack of trust & $\begin{array}{l}\text { Difficulty in finding a trusted party/ } \\
\text { person to lead the collaboration }\end{array}$ & $\begin{array}{l}\text { Cruijssen et al. (2007), } \\
\text { transport and logistics } \\
\text { industry, LSP perspective }\end{array}$ \\
\hline
\end{tabular}


Table 7 (continued)

\begin{tabular}{|c|c|c|c|}
\hline General Factor & Enablers/Barriers & Factor & $\begin{array}{l}\text { Paper, Industry and } \\
\text { Perspective }\end{array}$ \\
\hline $\begin{array}{l}\text { Presence of trust: } \\
\text { Factors which indicate } \\
\text { the presence or the } \\
\text { lack of partners } \\
\text { perceive each other as } \\
\text { credible and } \\
\text { benevolent }\end{array}$ & Lack of trust & Lack of trust & $\begin{array}{l}\text { Fawcett et al. (2008b); } \\
\text { Lambert et al. (1999); } \\
\text { Visser (2010), chemical } \\
\text { industry, logistics } \\
\text { collaboration and } \\
\text { outsourcing, shipper } \\
\text { perspective; }{ }^{*} \text {, FMCG } \\
\text { industry, retailer } \\
\text { perspective }\end{array}$ \\
\hline \multirow{4}{*}{$\begin{array}{l}\text { Presence of } \\
\text { understanding: } \\
\text { Factors which indicate } \\
\text { that the partners } \\
\text { understand each } \\
\text { other and the concept }\end{array}$} & \multirow[t]{4}{*}{ Lack of understanding } & $\begin{array}{l}\text { Lack of understanding of how to } \\
\text { incorporate green into buying }\end{array}$ & Walker et al. (2008) \\
\hline & & Poor understanding of the concept & $\begin{array}{l}\text { Akintoye et al. (2000), } \\
\text { construction industry, } \\
\text { manufacturer perspective }\end{array}$ \\
\hline & & $\begin{array}{l}\text { Understanding of the customer } \\
\text { situation and need }\end{array}$ & $\begin{array}{l}\text { Heikkilä (2002), } \\
\text { telecommunication } \\
\text { industry }\end{array}$ \\
\hline & & $\begin{array}{l}\text { Understanding of the partner's } \\
\text { resources and interests }\end{array}$ & Niderkofler (1991) \\
\hline \multirow{8}{*}{$\begin{array}{l}\text { Presence of } \\
\text { willingness to } \\
\text { change: Factors which } \\
\text { indicate the presence } \\
\text { or the absence of } \\
\text { inertia }\end{array}$} & \multirow[t]{6}{*}{$\begin{array}{l}\text { Presence of } \\
\text { willingness to change }\end{array}$} & $\begin{array}{l}\text { Adaptability to change and } \\
\text { innovativeness }\end{array}$ & Maheshwari et al. (2006) \\
\hline & & External willingness to change & $\begin{array}{l}\text { Reniers et al. (2010), } \\
\text { chemical industry, shipper } \\
\text { perspective }\end{array}$ \\
\hline & & $\begin{array}{l}\text { Need for change should be visible - } \\
\text { even palpable }\end{array}$ & Fawcett et al. (2008b) \\
\hline & & $\begin{array}{l}\text { Need for partnership must be } \\
\text { identified }\end{array}$ & $\begin{array}{l}\text { Ellram (1995), buyer } \\
\text { perspective; Simatupang } \\
\text { and Sridharan (2002) }\end{array}$ \\
\hline & & Relationship orientation & $\begin{array}{l}\text { Barrat (2004); Min et al. } \\
(2005)\end{array}$ \\
\hline & & Willingness and drive to change & $\begin{array}{l}*, \text { FMCG industry, } \\
\text { manufacturer perspective }\end{array}$ \\
\hline & \multirow[t]{2}{*}{$\begin{array}{l}\text { Lack of willingness to } \\
\text { change }\end{array}$} & Inertia & $\begin{array}{l}\text { Fawcett et al. (2008b); } \\
\text { Simatupang and Sridharan } \\
\text { (2002); Walker et al. (2008), } \\
\text { retailer perspective }\end{array}$ \\
\hline & & Lack of motivation towards integration & Richey et al. (2009) \\
\hline
\end{tabular}


Table 8: Allocation Risks

\begin{tabular}{|c|c|c|}
\hline General Factor & Factor & Paper, Industry, Perspective \\
\hline \multirow{2}{*}{$\begin{array}{l}\text { Uncertainty of additional costs: } \\
\text { Factors which indicate an uncertainty } \\
\text { if additional costs will occur in the } \\
\text { future }\end{array}$} & $\begin{array}{l}\text { Additional costs related to } \\
\text { coordination and controlling the } \\
\text { collaborative relationship }\end{array}$ & $\begin{array}{l}\text { Visser (2010), logistics outsourcing, } \\
\text { shipper perspective; *, FMCG } \\
\text { industry, retailer perspective }\end{array}$ \\
\hline & Costs are the main risks & $\begin{array}{l}*, \text { FMCG industry, manufacturer } \\
\text { perspective }\end{array}$ \\
\hline \multirow{3}{*}{$\begin{array}{l}\text { Uncertainty of change in key } \\
\text { personnel: Factors which indicate an } \\
\text { uncertainty that there will be a } \\
\text { change in the important persons }\end{array}$} & $\begin{array}{l}\text { Assignment of new employees to } \\
\text { partnership teams }\end{array}$ & $\begin{array}{l}\text { Landeros et al. (1995), buyer and } \\
\text { supplier perspective }\end{array}$ \\
\hline & $\begin{array}{l}\text { Reassignment of partnership } \\
\text { champion }\end{array}$ & $\begin{array}{l}\text { Landeros et al. (1995), buyer and } \\
\text { supplier perspective }\end{array}$ \\
\hline & $\begin{array}{l}\text { Vulnerability of collaboration project } \\
\text { biggest risk: if one party involved } \\
\text { terminates relation within project }\end{array}$ & $*$, FMCG industry, retailer perspective \\
\hline \multirow{2}{*}{$\begin{array}{l}\text { Uncertainty of change in ownership: } \\
\text { Factors which indicate an uncertainty } \\
\text { of a change in the ownership }\end{array}$} & $\begin{array}{l}\text { Acquisition of one of the partners by a } \\
\text { third party }\end{array}$ & $\begin{array}{l}\text { Landeros et al. (1995), buyer and } \\
\text { supplier perspective }\end{array}$ \\
\hline & $\begin{array}{l}\text { Having unequal share of financial } \\
\text { responsibility in the partnership }\end{array}$ & $\begin{array}{l}\text { Landeros et al. (1995), buyer and } \\
\text { supplier perspective }\end{array}$ \\
\hline \multirow{5}{*}{$\begin{array}{l}\text { Uncertainty of changes in the partner } \\
\text { base: Factors which indicate an } \\
\text { uncertainty due to changes in the } \\
\text { partner base }\end{array}$} & Entrance of new firms in the base & $\begin{array}{l}\text { Landeros et al. (1995), buyer and } \\
\text { supplier perspective }\end{array}$ \\
\hline & $\begin{array}{l}\text { Expanding for contracting } \\
\text { technological advantages in the base }\end{array}$ & $\begin{array}{l}\text { Landeros et al. (1995), buyer and } \\
\text { supplier perspective }\end{array}$ \\
\hline & Exiting of existing firms from base & $\begin{array}{l}\text { Landeros et al. (1995), buyer and } \\
\text { supplier perspective }\end{array}$ \\
\hline & $\begin{array}{l}\text { Increasing or decreasing purchases by } \\
\text { firms in the base }\end{array}$ & $\begin{array}{l}\text { Landeros et al. (1995), buyer and } \\
\text { supplier perspective }\end{array}$ \\
\hline & $\begin{array}{l}\text { Increasing or decreasing sales by firms } \\
\text { in the base }\end{array}$ & $\begin{array}{l}\text { Landeros et al. (1995), buyer and } \\
\text { supplier perspective }\end{array}$ \\
\hline \multirow{3}{*}{$\begin{array}{l}\text { Uncertainty of climatic factors: } \\
\text { Factors which indicate an uncertainty } \\
\text { of changes in the climate and their } \\
\text { impacts }\end{array}$} & Environmental issues & $\begin{array}{l}\text { Landeros et al. (1995), buyer and } \\
\text { supplier perspective }\end{array}$ \\
\hline & Natural disasters & $\begin{array}{l}\text { Landeros et al. (1995), buyer and } \\
\text { supplier perspective }\end{array}$ \\
\hline & Weather changes & $\begin{array}{l}\text { Landeros et al. (1995), buyer and } \\
\text { supplier perspective }\end{array}$ \\
\hline \multirow{2}{*}{$\begin{array}{l}\text { Uncertainty of competition: Factors } \\
\text { which indicate an uncertainty of } \\
\text { future competition and } \\
\text { competitiveness of the party }\end{array}$} & $\begin{array}{l}\text { Entrance of new competition or new } \\
\text { competitive advantages in the } \\
\text { industry }\end{array}$ & $\begin{array}{l}\text { Landeros et al. (1995), buyer and } \\
\text { supplier perspective }\end{array}$ \\
\hline & $\begin{array}{l}\text { Uncertainty of decreased } \\
\text { competitiveness }\end{array}$ & Maloni and Benton (1997) \\
\hline \multirow{8}{*}{$\begin{array}{l}\text { Uncertainty of economy: Factors } \\
\text { which indicate an uncertainty of a } \\
\text { change of the system and industry }\end{array}$} & Balance of payment & $\begin{array}{l}\text { Landeros et al. (1995), buyer and } \\
\text { supplier perspective }\end{array}$ \\
\hline & Depression & $\begin{array}{l}\text { Landeros et al. (1995), buyer and } \\
\text { supplier perspective }\end{array}$ \\
\hline & Deficits & $\begin{array}{l}\text { Landeros et al. (1995), buyer and } \\
\text { supplier perspective }\end{array}$ \\
\hline & Fiscal policies & $\begin{array}{l}\text { Landeros et al. (1995), buyer and } \\
\text { supplier perspective }\end{array}$ \\
\hline & Inflationary or deflationary trend & $\begin{array}{l}\text { Landeros et al. (1995), buyer and } \\
\text { supplier perspective }\end{array}$ \\
\hline & Interest rates & $\begin{array}{l}\text { Landeros et al. (1995), buyer and } \\
\text { supplier perspective }\end{array}$ \\
\hline & Monetary policies & $\begin{array}{l}\text { Landeros et al. (1995), buyer and } \\
\text { supplier perspective }\end{array}$ \\
\hline & Prosperous business cycle & $\begin{array}{l}\text { Landeros et al. (1995), buyer and } \\
\text { supplier perspective }\end{array}$ \\
\hline
\end{tabular}




\begin{tabular}{|c|c|c|}
\hline General Factor & Factor & Paper, Industry, Perspective \\
\hline \multirow{4}{*}{$\begin{array}{l}\text { Uncertainty of economy: Factors } \\
\text { which indicate an uncertainty of a } \\
\text { change of the system and industry }\end{array}$} & Recession & $\begin{array}{l}\text { Landeros et al. (1995), buyer and } \\
\text { supplier perspective }\end{array}$ \\
\hline & Recovery & $\begin{array}{l}\text { Landeros et al. (1995), buyer and } \\
\text { supplier perspective }\end{array}$ \\
\hline & Surpluses & $\begin{array}{l}\text { Landeros et al. (1995), buyer and } \\
\text { supplier perspective }\end{array}$ \\
\hline & Tax rates & $\begin{array}{l}\text { Landeros et al. (1995), buyer and } \\
\text { supplier perspective }\end{array}$ \\
\hline \multirow{5}{*}{$\begin{array}{l}\text { Uncertainty of government: Factors } \\
\text { which indicate an uncertainty of the } \\
\text { government }\end{array}$} & Americans with Disables Act & $\begin{array}{l}\text { Landeros et al. (1995), buyer and } \\
\text { supplier perspective }\end{array}$ \\
\hline & Domestic content requirements & $\begin{array}{l}\text { Landeros et al. (1995), buyer and } \\
\text { supplier perspective }\end{array}$ \\
\hline & Equal employment opportunity & $\begin{array}{l}\text { Landeros et al. (1995), buyer and } \\
\text { supplier perspective }\end{array}$ \\
\hline & Safety and health regulations & $\begin{array}{l}\text { Landeros et al. (1995), buyer and } \\
\text { supplier perspective }\end{array}$ \\
\hline & Wage and price controls & $\begin{array}{l}\text { Landeros et al. (1995), buyer and } \\
\text { supplier perspective }\end{array}$ \\
\hline \multirow{3}{*}{$\begin{array}{l}\text { Uncertainty of high dependency: } \\
\text { Factors which indicate an uncertainty } \\
\text { of the dependency on another party }\end{array}$} & $\begin{array}{l}\text { Contract uncertainty; parties are } \\
\text { mutually dependent }\end{array}$ & $\begin{array}{l}* \text {, FMCG industry, LSP, manufacturer } \\
\text { and retailer perspective }\end{array}$ \\
\hline & Dependency & $\begin{array}{l}\text { Niderkofler (1991); Visser (2010), } \\
\text { chemical industry, logistics } \\
\text { collaboration and outsourcing, } \\
\text { shipper perspective; *, FMCG } \\
\text { industry, LSP, manufacturer and } \\
\text { retailer perspective }\end{array}$ \\
\hline & Heavy reliance on the partner & Maloni and Benton (1997) \\
\hline $\begin{array}{l}\text { Uncertainty of losing clientele: } \\
\text { Factors which indicate an uncertainty } \\
\text { of losing customers }\end{array}$ & Risk of losing clientele to competitors & $\begin{array}{l}\text { Cruijssen et al. (2007), transport and } \\
\text { logistics industry, LSP perspective }\end{array}$ \\
\hline \multirow{2}{*}{$\begin{array}{l}\text { Uncertainty of losing transparency: } \\
\text { Factors which indicate an uncertainty } \\
\text { of a change in transparency in the } \\
\text { future }\end{array}$} & $\begin{array}{l}\text { Danger of commercial usage of } \\
\text { confidential information }\end{array}$ & *, FMCG industry, LSP perspective \\
\hline & Uncertainty of losing transparency & $\begin{array}{l}\text { Visser (2010), chemical industry, } \\
\text { shipper perspective; }{ }^{*}, \text { FMCG } \\
\text { industry, manufacturer perspective }\end{array}$ \\
\hline \multirow{5}{*}{$\begin{array}{l}\text { Uncertainty of organizational } \\
\text { socialization: Factors which indicate } \\
\text { an uncertainty of changes in the } \\
\text { process through which new } \\
\text { employees learn to adapt to the } \\
\text { organizational culture }\end{array}$} & Enriching team potency & $\begin{array}{l}\text { Landeros et al. (1995), buyer and } \\
\text { supplier perspective }\end{array}$ \\
\hline & $\begin{array}{l}\text { Establishing the partnership team's } \\
\text { importance, purpose and identity }\end{array}$ & $\begin{array}{l}\text { Landeros et al. (1995), buyer and } \\
\text { supplier perspective }\end{array}$ \\
\hline & $\begin{array}{l}\text { Setting up relationships among } \\
\text { members }\end{array}$ & $\begin{array}{l}\text { Landeros et al. (1995), buyer and } \\
\text { supplier perspective }\end{array}$ \\
\hline & Setting team tasks & $\begin{array}{l}\text { Landeros et al. (1995), buyer and } \\
\text { supplier perspective }\end{array}$ \\
\hline & Training existing and new members & $\begin{array}{l}\text { Landeros et al. (1995), buyer and } \\
\text { supplier perspective }\end{array}$ \\
\hline \multirow{4}{*}{$\begin{array}{l}\text { Uncertainty of performance } \\
\text { problems: Factors which indicate an } \\
\text { uncertainty of problems with the } \\
\text { performance and quality in the future }\end{array}$} & Data reliability & $*$, FMCG industry, retailer perspective \\
\hline & Late or missed deliveries & $\begin{array}{l}\text { Landeros et al. (1995), buyer and } \\
\text { supplier perspective }\end{array}$ \\
\hline & Quality performance problems & $\begin{array}{l}\text { Landeros et al. (1995), buyer and } \\
\text { supplier perspective; *, FMCG } \\
\text { industry, retailer perspective }\end{array}$ \\
\hline & Uncertainty of outcome & ${ }^{*}$, FMCG industry, retailer perspective \\
\hline
\end{tabular}

